\title{
ABUNDANCE AND THREATS TO THE SURVIVAL OF THE SNOW LEOPARD - A REVIEW
}

\author{
KAMILA ANNA VALENTOVÁ* \\ Institute for Environmental Sciences, Faculty of Science, Charles University, Benátská 2, 12801 Prague, Czech Republic \\ *Corresponding author: ValentovaKamila@seznam.cz
}

\begin{abstract}
Snow leopard (Panthera uncia) is an endangered species and its population size is steadily declining. This review attempts to introduce and analyse the main factors threatening its survival in each of the countries in which it occurs: China, Bhutan, Nepal, Pakistan, Afghanistan, Tajikistan, Uzbekistan, Kyrgyzstan, Kazakhstan, Russia and Mongolia. To conserve the remaining snow leopard populations, it is necessary to determine where it occurs in the various areas. Here, recent data on its worldwide distribution are presented. Snow leopard has a very secretive lifestyle, which makes it difficult to estimate its abundance. Therefore, I also present an overview of the methods, such as searching for signs of its presence, capture-recapture, predator : prey biomass ratios, photographic-capture rate and genetic analyses, used for estimating the abundance of snow leopard in different studies and discuss their advantages and disadvantages.
\end{abstract}

Keywords: snow leopard, abundance, threats, worldwide distribution, conservation

\section{Introduction}

Snow leopard, Panthera uncia (Schreber 1775), syn. Uncia uncia is a member of the genus Panthera in the family Felidae. It is most closely related to the tiger, Panthera tigris (Jackson et al. 2008). The snow leopard is whitish-grey (tinged with yellow) in colour, and patterned with dark grey rosettes and spots (McCarthy and Chapron 2003). Unlike other big cats, it has under-developed fibro-elastic tissue in its vocal apparatus (Rajput 2009), so it is not able to make a full deep roar. In general, snow leopards live solitarily, though groups of up to six snow leopards are reported (McCarthy and Chapron 2003). In the 1972 IUCN's Red List of Threatened Animals it is listed as an "endangered" species (EN) due to its small population worldwide.

Its main habitat consists of alpine and sub-alpine regions with rugged and steep terrain separated by ridges, cliffs, rocky outcrops and gullies (Schaller 1977; Jackson and Ahlborn 1989; Ale et al. 2014). Nevertheless, it occurs even in flat and rolling terrain in Tibet and Mongolia, wherever there is ample cover in which they can hide (Jackson et al. 2008). Usually it inhabits areas at altitudes of from 3,000-4,500 m. However, at the northern limits of its range it occurs at much lower altitudes: $900-2,500 \mathrm{~m}$ (McCarthy et al. 2003). Its home range for instance in Nepal varies between 10 to $40 \mathrm{~km}^{2}$ (Jackson and Ahlborn 1989). However, it may reach up to $140 \mathrm{~km}^{2}$, in Mongolia, due to the lower prey densities and open terrain (McCarthy et al. 2005). Snow leopard density ranges from 0.1 to 10 or even more individuals per $100 \mathrm{~km}^{2}$ (Jackson et al. 2008).

Snow leopard's main natural prey includes ibex (Capra ibex), argali (Ovis ammon) and bharal or blue sheep (Pseudois nayaur) (Jackson et al. 2008; McCarthy et al. 2008). The natural distribution of the snow leopard is closely correlated with that of its prey. One snow leopard needs about 20 to 30 adult blue sheep annually (Jackson et al. 2008). For instance, the habitat of blue sheep is spaced out in mountainous terrain from the Qilian Mountains in the north to the Himalayas in the south (Aryal et al. 2014), which includes Nepal, India, China, Pakistan and Mongolia. Unfortunately, there are no accurate estimates of blue sheep abundance (Schaller 1977; Oli et al. 1993). Its other prey species include pika (Ochotona spp.), hares (Lepus spp.), marmot (Marmota spp.), game birds, and small rodents (Jackson et al. 2008). Domestic livestock is a potential prey of snow leopard, e.g., in many cases snow leopard opportunistically kills more domestic livestock than wild prey. Our knowledge of its diet range and especially of the relative importance of individual species in its diet is still anecdotal and therefore, it would be appropriate to conduct additional surveys to better understand the trophic interactions in leopard-prey systems (Aryal et al. 2014).

\section{Threats to the Snow Leopard}

The main threats to the snow leopard include illegal trade, conflict with locals (human-snow leopard conflict), lack of conservation, awareness and policy, and climate change (Jackson et al. 2008).

\section{Human-Snow Leopard Conflict}

Conflict with local people is the most significant threat to snow leopards. This conflict is caused by snow leopards killing livestock, which leads to retaliatory killing (Jackson et al. 2008). Snow leopard home ranges overlap extensive agro-pastoral land, which is located inside and outside protected areas. The rapid increase in the killing of livestock is caused by the decline in the abundance of wild prey due to low primary productivity, competition for forage with livestock and the hunting of ungulates for meat (Bagchi and Mishra 2006; Jackson et al. 2008). Snow leopard's population density is positively correlated with 
the density of its prey (McCarthy et al. 2003). Livestock is an important food source for snow leopards; in some areas it makes up 58\% of their food (Jackson et al. 2008).

Even though killing snow leopard is prohibited, cases of retaliatory killings of snow leopard by the herders are still reported, for instance in Nepal in the Kanchenjunga Conservation Area (KCA) (Ikeda 2014). Most herders have a negative attitude to snow leopard conservation programmes because of insufficient compensation for the damage they cause to their livestock and the un-realistic procedure for verifying that livestock has been killed by a snow leopard (Ikeda 2004). The economic damage is much greater than the compensation the herders get from the government. There are a few methods for estimating the monetary value of damage to livestock that were used in previous studies, such as half of the per capita average income in Himachal Pradesh, India (Mishra 1997) or a quarter of the per capita average annual income in Nepal (Oli et al. 1994). Ikeda in the KCA estimated the monetary value of damage to livestock in terms of local herder's economy in the Ghunsa Valley, Nepal (Ikeda 2014). The economic effect of loss of a herder's livestock differs between areas. For example, in western Nepal, herders possess sheep, goats, yaks and yak hybrids, while in eastern Nepal, yak and yak hybrid pastoralism is more important, so in general they have fewer animals in contrast with the hundreds of goats and large flocks of sheep in western Nepal. Therefore, the effect of losing one animal is greater in eastern than in western Nepal (Ikeda 2004). However, occasionally more than 100 sheep or goats are killed by snow leopard (so-called surplus or mass killing), which may cause a huge economic loss to local herders (Shrestha, pers. comm.) For households with the average herd size (36.6 head in KCA) the annual damage by snow leopards does not have such a big effect on their livelihood. However, in the worst scenario, for households with medium or small-sized herds $(<40$ head) the risk becomes unsustainable and they have to cease depending on yak pastoralism (Ikeda 2004).

Killing of snow leopards in retaliation for their killing livestock and the reduction in the abundance of natural prey is inherently very challenging in the Himalayan region (India, Nepal, Bhutan, Tibetan Plateau and other southern China), Karakorum and Hindu Kush (southwest China, Pakistan and Afghanistan). The abundance of the natural prey of snow leopard has been greatly reduced by illegal hunting in the Commonwealth of Independent States and western China (Kyrgyzstan, Kazakhstan, Xinjiang province of China, Uzbekistan and Tajikistan) (Jackson et al. 2008).

\section{Illegal Trade}

Illegal trade in snow leopards is also a serious threat to their survival. Snow leopards are killed not just for killing livestock but also for commercial purposes. There is a big demand for snow leopard pelts, followed by their claws, meat, male organs and bones as substitutes for tiger bones in Chinese medicine (Theile 2003). Because of the strong Chinese economy the illegal trade in snow leopards increases, for instance with adjoining Mongolia (Wingard and Zahler 2006) and Afghanistan, where it is difficult to stop because of the current military situation there (Habibi 2004). With the fall of the Soviet Union in the 1900s, in Kyrgyzstan and other recently independent states, increased unemployment and corruption in mountainous regions led to a growth in the black market trading in wildlife products (McCarthy et al. 2010). For instance, in Kyrgyzstan people living in villages close to protected areas are poorly paid and in some cases have to resort to poaching wildlife within the park boundaries $(\mathrm{McCa}-$ rthy et al. 2010). Nowadays some of the former socialist republics continue to promote a sustainable developmental agenda (McCarthy et al. 2010). Today, the level of poaching is lower, but in many of the former Soviet republics it continues.

\section{Lack of Awareness and Policy}

The general lack of awareness, at both local and national levels, for the need to conserve wildlife, especially predators, further hinders conservation efforts (Jackson et al. 2008).

To estimate abundance of snow leopard in some cases, e.g. when genetic analyses are used, it is necessary to transport samples across countries. Impossibility of transporting samples between countries complicates such surveys, especially in areas adjacent to politically sensitive international borders. In the IUCN's research, lack of trans-boundary cooperation is challenging at almost every location where snow leopards occur such as the Himalayan region and Commonwealth of Independent States and western China (Jackson et al. 2008). For instance, in Nepal, there is only one laboratory in Kathmandu specializing in wildlife, which is insufficient (Bikram Shrestha, pers. comm.). The majority of herders in Nepal complain about insufficient project management in terms of reliability and transparency (Ikeda 2004).

In some areas, e.g., in Kyrgyzstan, there is an insufficient legislative system for protecting reserves. $\mathrm{McCa}$ rthy et al. (2010) compared the composition of species in an unprotected area which is used for hunting by foreign companies and a strictly protected national park (Sary Chat) in the Tien Shan Mountains in eastern Kyrgyzstan. Even though hunting is not permitted at Sary Chat, cases of poaching by rangers and local villagers are reported (Koshkarev and Vyrypaev 2000). On the other hand, after the breakup of the Soviet Union, Jangart was established as a foreign currency hunting reserve hosting non-nationals who come to Kyrgyzstan to hunt ungulates (McCarthy et al. 2010). Unexpectedly, the numbers of photographs of ungulates recorded by camera traps in the unprotected area (Jangart) were higher than in the protected area for most species (McCarthy et al. 2010). A possible explanation is that Jangart is more isolated from 
local villages than Sary Chat, where rangers and their families have settled along the edges of the park $(\mathrm{McCa}-$ rthy et al. 2010).

This reflects a fundamental problem with the reserves in Kyrgyzstan - a deficiency in auxiliary enterprises for local people. The government replaced park staff and a nongovernmental organization $(\mathrm{CBF}=$ Community Business Forum) and the International Snow Leopard Trust were involved, but nonetheless there is still evidence of continuing poaching of some carnivores in and around the reserve (McCarthy et al. 2010).

Ineffective enforcement of the law and institutional incapacity are problems mainly along the northern edge of the distribution of snow leopards (Russia, Mongolia, Tien Shan ranges and Altai in China), Karakhorum and Hindu Kush (Afghanistan, southwest China and Pakistan) (Jackson et al. 2008).

Military conflict has also affected snow leopards, primarily by destroying their habitats (landmines), secondarily by encouraging trade in wildlife (Jackson et al. 2008). This is a serious problem in the Himalayan region and Commonwealth of Independent States and western China.

\section{Climate Change}

Climate change is a serious threat to biodiversity (McCarty et al. 2001; Thomas et al. 2004; Beaumont et al. 2011). In general, climate change destabilizes systems and their management, such as the balance between resource use by locals and wildlife biodiversity (Comiso 2003; Mishra et al. 2004; Namgail et al. 2007; Sharma and Tsering 2009). The United Nations Intergovernmental Panel on Climate Change forecasts that the global temperatures will increase by something between 1.4 and $5.8{ }^{\circ} \mathrm{C}$ by 2100 (IPCC 2001; Locky and Mackey 2009). Most areas in snow leopard home ranges, such as high altitudes and cold deserts in the Trans-Himalayan region, are among the most vulnerable ecosystems in terms of the effects of climate change (Christensen and Heilmann-Clausen 2009; Dong et al. 2009; Sharma and Tsering 2009; Xu et al. 2009; Aryal et al. 2012a,b).

The tendency of snow leopards to move to lower altitudes will increase due to the movement of their prey, such as blue sheep in the Trans-Himalayas, due to substantial changes in vegetation communities; grasses and many species of shrubs are no longer found in sufficient abundance at high altitudes and consequently blue sheep move to forage at low altitudes where they more likely to encounter and kill livestock (Table 1, Aryal et al. 2013). Table 1 shows the predicted effect of climate change on the livelihood of the people, blue sheep and snow leopard, which are interrelated. According to the predictions based on bioclimatic models, about $30 \%$ of snow leopard habitat may be lost in the Himalayas due to a shifting treeline and consequent shrinking in the alpine zone, mostly along the southern edge of the range and in river valleys (Forrest et al. 2012). In most of the snow leopard's range, people practice rotational grazing in which corrals are located at different altitudes. Therefore, livestock killing is correlated with herding practices (Shrestha pers. comm.). Increased crop raiding by blue sheep and the killing of livestock by snow leopards have adversely affected the livelihood of local people (Aryal et al. 2013).

\section{Methods of Estimating Snow Leopard Abundance}

To optimize the management of snow leopard, it is necessary to know its distribution within an area and relative abundance in different habitats (Sheng et al. 2010). Its secretive lifestyle makes estimating its abundance quite difficult. Methods used for estimating snow leopard abundance include search for signs of their presence, capture-recapture, predator : prey biomass ratios, pho-

Table 1 Overall effect of climate change on four parameters. Source: Interview with local people $(n=221)$. Data are the percentages of the 221 respondents that agreed with the statement (Source: Aryal et al. 2013).

\begin{tabular}{|c|c|c|c|}
\hline Rangelands (\%) & Livelihood (\%) & Blue sheep (\%) & Snow leopard (\%) \\
\hline $\begin{array}{l}\text { Reduction in water } \\
\text { sources (18) }\end{array}$ & $\begin{array}{l}\text { Reduction in food and drier } \\
\text { farmland (9) }\end{array}$ & Reduction in numbers (38) & $\begin{array}{l}\text { Reduction in numbers and fewer } \\
\text { sightings ( } 41 \text { ) }\end{array}$ \\
\hline Reduction in grass (33) & Reduction in livestock (4) & Crop raiding (16) & $\begin{array}{l}\text { Increase in attacks on livestock due } \\
\text { to decrease in natural prey (24) }\end{array}$ \\
\hline Drier (12) & $\begin{array}{l}\text { Health problems with new } \\
\text { diseases ( } 3 \text { ) }\end{array}$ & $\begin{array}{l}\text { Movement downwards } \\
\text { towards farmland (14) }\end{array}$ & Approaching villages (13) \\
\hline Reduction in snowfall (27) & $\begin{array}{l}\text { Reduction in drinking water and } \\
\text { fewer irrigation channels ( } 36)\end{array}$ & Sightings near villages (4) & $\begin{array}{l}\text { Change in use of habitat and increase } \\
\text { in their tendency to kill domestic live- } \\
\text { stock rather than natural prey (22) }\end{array}$ \\
\hline $\begin{array}{l}\text { Move towards } \\
\text { desertification (10) }\end{array}$ & $\begin{array}{l}\text { Changes in the timing and } \\
\text { cultivation of agricultural crops ( } 27 \text { ) } \\
\text { Increase in wind speed } \\
\text { Economic crisis ( } 7 \text { ) } \\
\text { Water seepage and damage } \\
\text { to traditional houses (14) }\end{array}$ & $\begin{array}{l}\text { Reduction in grazing land (20) } \\
\text { Change in habitats use ( } 8 \text { ) }\end{array}$ & \\
\hline
\end{tabular}


tographic-capture rate and genetic analyses (McCarthy et al. 2008). No photograph of a wild snow leopard existed until 1980 (Schaller 1980). Now camera traps are available they have replaced live-capture (direct capture of an animal), which is almost impossible to use because of their very low rate of encounter: about 3/1,000 trapnights (McCarthy et al. 2008).

\section{Sign Surveys (SLIMS)}

Snow Leopard Information Management System (SLIMS) was developed recently to monitor the abundance of snow leopards and their prey (Jackson and Hunter 1996). The system is based on standardized sign surveys, which are used regularly. Sign surveys result in indices of relative abundance of snow leopards, which can be used to compare areas with similar topographies (Ale et al. 2014). This method can be used to monitor trends in abundance in the same area over a long time scale, so long as it is complemented by additional methods such as genetic analyses (e.g., Janecka et al. 2008) or remote cameras (e.g., McCarthy et al. 2008). SLIMS is cheap, has a minimal impact on the species studied and, therefore, is most commonly used for monitoring snow leopards (Schaller 1977; Schaller 1998; Wilson and Delahay 2001; Wolf and Ale 2009). As the majority of ecological problems can be tackled using only indices of density, absolute estimates of density are unnecessary luxuries (Caughley 1977), SLIMS may be sufficient in most cases.

The guesstimate of Snow Leopard numbers based on sign abundance follows Jackson and Hunter (1996): 20 signs per kilometre indicates 10 individuals per $100 \mathrm{~km}^{2}-$ a crude, quick and easy-to-use method, which has been useful in conservation planning in countries where resources are scarce (Ale et al. 2014). It is appropriate to space out the cameras: install at least one camera per approximately $25 \mathrm{~km}^{2}$, as this is assessed to be the minimum home range of a female adult snow leopard (Jackson and Hunter 1996; Ale et al. 2014).
To determine where to locate transects for sign survey, it is necessary to hike through the region and detect all sites where suitable habitat and terrain exist for snow leopard and where its prey occur. As Ale at al. (2014) did in Nepal, it is important to identify sites, which are often used by snow leopard to move around in its home range such as narrow valleys, trails, ridgelines and cliff-edges (Jackson and Hunter 1996). To locate these sites it is helpful to use 1:50,000 topographic maps as used by Ale et al. (2014) or the 1:100,000 topographic maps used by McCarthy et al. (2008) in Kyrgyzstan and China.

After locating transects (sites with high probability of snow leopard occurrence) they are searched for signs of snow leopards. In addition, to provide useful information for comparison with that gathered along sign transects, it is possible to record signs between transect lines (McCarthy et. al. 2008). Signs demonstrating snow leopard presence include scent (or spray) marks, scrapes, faeces, pugmarks (footprints) and rocks or boulders that snow leopards use to deposit their scent or cheek-rub (Ale et al. 2014). Scrapes and scent marks are more expensive to detect than faeces and pugmarks. However, they may give us more biological and ecological information (Schaller 1977, 1998).

According to surveys conducted in the Mustang District of Nepal's Annapurna Conservation Area (Table 2), scats and scrapes are detected most frequently, scent sprays and pugmarks less often. Ale et al. (2014) report that the probability of finding signs is highest in spring $(10.2$ signs $/ \mathrm{km})$ and lowest in summer $(2.1$ signs $/ \mathrm{km})$, which may be due to snow leopard and its prey, blue sheep, moving to higher locations, which are less accessible to the observers (Jackson and Hunter 1996; Oli and Rogers 1996). Another possible explanation is that snow leopard signs are obliterated by livestock in summer (Ale et al. 2014). For a better comparison of the effectiveness of sign surveys in different seasons it is also necessary to conduct sign surveys during summer and spring in

Table 2 Signs indicating the abundance of snow leopards at Mustang, Annapurna (Source: Ale et al. 2014).

\begin{tabular}{|c|c|c|c|c|c|c|c|c|c|c|c|c|}
\hline & Transect & $\begin{array}{c}\text { Length } \\
\text { (km) }\end{array}$ & Feces & Pugmark & Scrape & Spray & Hair & Total & $\begin{array}{c}\text { Total } \\
\text { sign/km }\end{array}$ & $\begin{array}{l}\text { Sign } \\
\text { sites }\end{array}$ & $\begin{array}{c}\text { Sign } \\
\text { sites/km }\end{array}$ & $\begin{array}{c}\text { Scrape/ } \\
\text { km }\end{array}$ \\
\hline \multicolumn{13}{|c|}{ Season } \\
\hline Autumn & 9 & 7.2 & 19 & 10 & 33 & 4 & & 66 & 9.2 & 46 & 6.4 & 4.6 \\
\hline Spring & 15 & 11.0 & 15 & 6 & 90 & & 1 & 112 & 10.2 & 38 & 3.5 & 8.2 \\
\hline Summer & 27 & 19.4 & 22 & 3 & 16 & & & 41 & 2.1 & 23 & 1.2 & 0.8 \\
\hline Total & & 37.6 & 56 & 19 & 139 & 4 & 1 & 219 & 5.8 & 107 & 2.8 & 3.7 \\
\hline \multicolumn{13}{|c|}{ Study area } \\
\hline $\begin{array}{l}\text { Lower } \\
\text { Mustang }\end{array}$ & 3 & 24.4 & 45 & 15 & 56 & 4 & 1 & 121 & 5.0 & 77 & 3.2 & 2.3 \\
\hline $\begin{array}{l}\text { Upper } \\
\text { Mustang }\end{array}$ & 18 & 13.2 & 11 & 4 & 83 & & & 98 & 7.4 & 30 & 2.3 & 6.3 \\
\hline Total & & 37.6 & 56 & 19 & 139 & 4 & 1 & 219 & 5.8 & 107 & 2.8 & 3.7 \\
\hline
\end{tabular}


other countries. If such surveys show that the probability of finding signs is consistently higher in spring, then it might be sufficient to conduct just spring surveys.

For estimates of predator numbers using SLIMS a standard methodology should be used, e.g., for comparison of sign transects between various areas, unit transect lengths should be compared (Ale et al. 2014). It is also necessary to reduce observation bias. One of the options is that all observers involved obtain the same training to avoid disagreements over what constitutes a snow leopard scrape, which can lead to erroneous results (McCarthy et al. 2008). Environmental conditions (e.g. snow cover) and accessibility of the terrain can also affect the results. With respect to the latter, in Qinghai (China), where snow leopards mark the bases of hills flanking broad valleys where their travel routes are less accessible (Schaller et al. 1988; Ale et al. 2014). Also in the Himalayas, where wide U-shaped valleys and broad ridges are common, it is difficult to find signs of snow leopard (Jackson and Hunter 1996).

\section{Predator : Prey Biomass Ratio}

Predator-prey models of population dynamics predict that there is a negative feedback between prey and predator biomass (Fuller and Sievert 2001; Carbone and Gittleman 2002). This is indirectly supported by an observation at Sary Chat in Kyrgyzstan where a decrease in snow leopard abundance was followed by an increase in that of ungulates (McCarthy et al. 2008). This provides the basis for another method of estimating the size of snow leopard populations, the predator : prey biomass ratio, from which the abundance of snow leopard can be estimated if one knows its prey biomass (Fuller and Sievert 2001; Carbone and Gittleman 2002), which is estimated using SLIMS (Jackson and Hunter 1996).

For measuring the number of snow leopard prey it is necessary to select a favourable point at each site, from where one does not disturb the animals and from where it is possible to localise and determine group size, age and sex of each individual (McCarthy et al. 2008). For observations, it is appropriate to use binoculars and spotting scopes. After this, one calculates the total prey biomass by multiplying the number of animals observed by the average prey weight (Fedosenko and Blank 2001). Ungulate biomass per $100 \mathrm{~km}^{2}$ can then be recalculated to leopard biomass by a simplified conversion factor of $10,000 \mathrm{~kg}$ prey for $90 \mathrm{~kg}$ of predator (Carbone and Gittleman 2002), which can be converted to numbers using an average weight for snow leopard of 50 kilograms (McCarthy et al. 2008). The predator:prey ratio may be, however, biased due to competition for food with other species of predator such as wolves (McCarthy et al. 2008).

Another, more sophisticated method proposed by Aryal et al. (2014) is that of the maximum number of snow leopards that can be supported by the prey available (its carrying capacity, $K$ ), which is calculated as

$$
K=A /(E S S R \times A H R S)
$$

with:

$$
E S S R=P B Y /(P D \times S U F \times B D \times E H D)
$$

where:

$A$ - area;

AHRS - average home range size (about $22.6 \mathrm{~km}^{2} /$ individual);

ESSR - ecological sustainable stocking rate;

$P B Y$ - prey biomass /snow leopard/year ( 548kg/year, $1.5 \mathrm{~kg} /$ day - Schaller 1977);

$P D$ - total prey biomass $/ \mathrm{km}^{2}$;

SUF - safe use factor - the total biomass production of the ecological site that is available for use by animals with the remaining biomass available for ecological sustainability (Alberta Sustainable Resource Development 2004; Aryal 2007; Aryal et al. 2014); in Nepal, Aryal et al. (2014) used 25\% for SUF due to the presence of other predators (lynx, red fox, jackal, wolf); it means that snow leopards can consume just $25 \%$ of the total sheep population and the rest is available to other predators;

$B D$ - birth : death, for instance for blue sheep in Nepal it is presumed to be $2: 1$, based on the estimate that $50 \%$ of blue sheep die between birth and 2 years of age in the Dhorpatan Hunting Reserve (Schaller 1977; Wegge 1979);

$E H D$ - environment and human disturbance factors in the habitat (poaching, livestock grazing) where the grassland is that sustains the prey : predator population; e.g., the Upper Mustang in Nepal has a lower young-toold male ratio than Lower Mustang due to its lower productivity (Ale et al. 2014); productive grasslands are expected to have a higher proportion of young males while the opposite would be the case for ungulate populations occupying degraded grasslands (Ale et al. 2014).

\section{Genetic Analyses}

Genetic analysis of faecal DNA is a promising method of estimating the abundance of snow leopard (McCarthy et al. 2008) and with a better developed format for scat collection, it would provide a better understanding of territoriality or marking behaviour. Genetic analysis is the only method that provides information about genetic relationships, including the source of dispersers (Gese 2001; McCarthy et al. 2008). The other advantage is that the estimates are not subject to observer bias as they based on using specialized equipment and prior training (McCarthy et al. 2008). Genotyping of faeces may generate a higher number of known individuals than visual discrimination based on photographs and provide minimum population estimates. For instance, for Sary Chat, Jangart, and Tomur the estimates based on photographs were 3, 5 and 9 individuals respectively, while those based on genotypes were 9, 9 and 17 (McCarthy et al. 2008).

Nevertheless, one major disadvantage of these methods is the price (about USD 50-225 for one sample) and 
also logistics of transporting faecal material between countries (McCarthy et al. 2008). One of the alternatives for reducing costs could be in-country laboratories for processing the genetic data. Shrestha, who is conducting studies in Nepal, processes samples in a laboratory in Kathmandu and cooperates with his colleagues in Prague for further analyses. It would, however, be more effective if it were possible to export the samples between countries.

To utilize genetic analyses for monitoring snow leopards, first samples must be collected. For instance, $\mathrm{McCa}$ rthy et al. (2008) in China and Kyrgyzstan received their samples (suspected snow leopard faeces) from study areas which they determined using SLIMS. Scent pads or hair samples from cheek rubbing (Weaver et al. 2005) can also be used to create a more accurate method of sampling. It is important to minimize samples which do not belong to snow leopard by selecting them according to their shape, location and size. McCarthy et al. (2008) avoided contamination by collecting faecal samples wearing latex gloves and using plastic spoons and then storing in individual 5-ml transport tubes containing $4 \mathrm{ml}$ of $90 \%$ ethanol. In general, to avoid errors in scat collection, it is appropriate to obtain samples of scrapes to increase the confidence that it is a snow leopard sign. After collection of samples, DNA extraction is carried out in a laboratory and the polymerase chain reaction (PCR) is set for a low-quantity of DNA in the samples. For DNA extraction it is possible to use stool kits, e.g., the Qiagen stool kit (Qiagen Inc., Valencia, CA) and protocols inclusive of negative controls to monitor for contamination. After PCR, the sample of an approximately 160 base-pair section of the cytochrome $\mathrm{B}$ gene of the mitochondrial DNA control region is sequenced (McCarthy et al. 2008). To identify which species deposited each faecal sample, stated primers and formerly published methods are used (Farrell et al. 2000; Onorato et al. 2006). To distinguish individuals of snow leopard, it is appropriate to have as many primers (polymorphic microsatellite loci) as possible. McCarthy et al. (2008) used 10 polymorphic microsatellite loci to identify individual snow leopards.

\section{Camera Traps}

Camera trapping has a wide use ranging from birds to mammals (Cutler and Swann 1999). It is used to estimate presence/absence (Foster and Humphrey 1995; Whitefield 1998), population characteristics (Karanth 1995; Karanth and Nichols 1998) daily activity patterns (Pei 1998; Azlan and Sharma 2006; Sathyakumar et al. 2011), and abundance (Carbone et al. 2001; O’Brien et al. 2003; Rowcliffe et al. 2008) of animals. Camera trapping is considered to be a modern non-invasive method (Mace et al. 1994; Karanth 1995; Karanth and Nichols 1998; Carbone et al. 2001; Mackenzie and Royle 2005) for monitoring cryptically living animals, such as snow leopard, and for population studies of species whose individuals can be recognized by marks (Karanth 1995; Carbone et al. 2001; Sathyakumar et al. 2011). It is more dependable than other methods when sample sizes are small and species are scarce (Carbone et al. 2001; Sathyakumar et al. 2011). Karanth et al. (2002) and Henschel and Ray (2003) provide detailed methods for using camera traps for estimating the densities of tigers (Panthera tigris) and leopards (Panthera pardus). Camera traps are also more suitable for local teams, including staff of protected areas, so that they can carry out these surveys independently and sustainably over a long period (Alexander et al. 2015).

However, there are also constraints. They are difficult to use in areas that are difficult to access due to dense vegetation, steepness or are located at great distances (Sathyakumar et al. 2011). For instance, the high sensitivity of infrared sensor camera units used by Sathyakumar et al. (2011) resulted in them capturing wind-caused movement of vegetation, which resulted in many photographs being taken of vegetation. In bad weather, such as high rainfall or extremely low temperature, the cameras sometimes fail.

We define a "photo event" as any photograph or set of photographs of a snow leopard at photo-trap site even though it is not possible to identify the individual (McCarthy et al. 2008). Wilson and Anderson (1985) define photographic rate as an index of relative abundance (RAI), calculated as the number of photographs of a species divided by the number of trap-days per site (in most cases 100 trap-nights). To obtain more accurate results, it is appropriate to count photographs of individuals captured more than once within one hour by the same camera as one photograph (Bowkett et al. 2007; Sathyakumar et al. 2011). The number of trap-nights depends on the number of cameras and on the number of days they are operated. For instance, McCarthy et al. (2008) conducted a survey spanning 1,078 to 1,180 trap-nights in each area. In most cases, cameras are oriented towards the south or north so that they are less affected by sun light. In general, the first choice for camera trapping are marking sites along suspected snow leopard trails, e.g., along high, well-defined and narrow ridgelines or valley bottoms or immediately adjacent to frequently scent-sprayed rocks and scrapes (Jackson et al. 2006; Ale et al. 2014). Camera sites are then usually arranged about $2 \mathrm{~km}$ from each other in a circular pattern, $45-50 \mathrm{~cm}$ above the ground, with a 90-second delay between photographs, as in McCarthy at al. (2008). An infrared sensor is an advantage (Sathyakumar et al. 2011).

\section{Capture-Recapture Method}

The camera capture-recapture method is considered to be a feasible way of estimating densities of individually recognizable animals with large home ranges and low densities, so it is especially suitable for snow leopard (Silver et al. 2004; McCarthy et al. 2008). However, when the densities are very low, this method can be vulnerable to logistical constraints (McCarthy et al. 2008).

There are several theories on how to create a spatial buffer of potential capture locations to cover the total 
sampling area (Fig. 1, McCarthy et al. 2008). One of them is the mean-maximum-distance-between-recaptures, formulated on the basis of capture-recapture of small mammal populations (Wilson and Anderson 1985). This theory is often criticised in the literature (McCarthy et al. 2008) because its dependability is thought to decrease when trap rate declines and home range size increases (Wilson and Anderson 1985). Another possibility is to use maximum distance between recaptures for the buffer (O'Brien et al. 2003). The former theory is not well supported in the literature and often criticized (McCarthy et al. 2008), as it is suspected that the dependability decreases when trap rate declines and home range size increases (Wilson and Anderson 1985). A third theory or method is the use of the average minimum reported home-range size or average home-range size of the species (Otis et al. 1978). It is not that easy to estimate the size of the home range because it depends on the accessible food biomass. Standard home range size is about $22.6 \mathrm{~km}^{2} /$ individual. Another issue is that data are not available for some areas of snow leopard occurrence. The Tien Shan Mountains are a good example (McCarthy et al. 2008). Home range size of carnivores is often inversely correlated with prey biomass (Fuller and Sievert 2001). Therefore, it is appropriate to take into account ungulate densities (Table 1) and fit the data by a linear regression. McCarthy et al. (2008) calculate the effective study area according to the methods described above (Fig. 1): mean maximum distance moved between recaptures, half mean maximum distance moved by recaptured animals, radius of the average minimum home range or average home range and radius of the estimated home range from ungulate densities (McCarthy et al. 2008). By choosing one of these

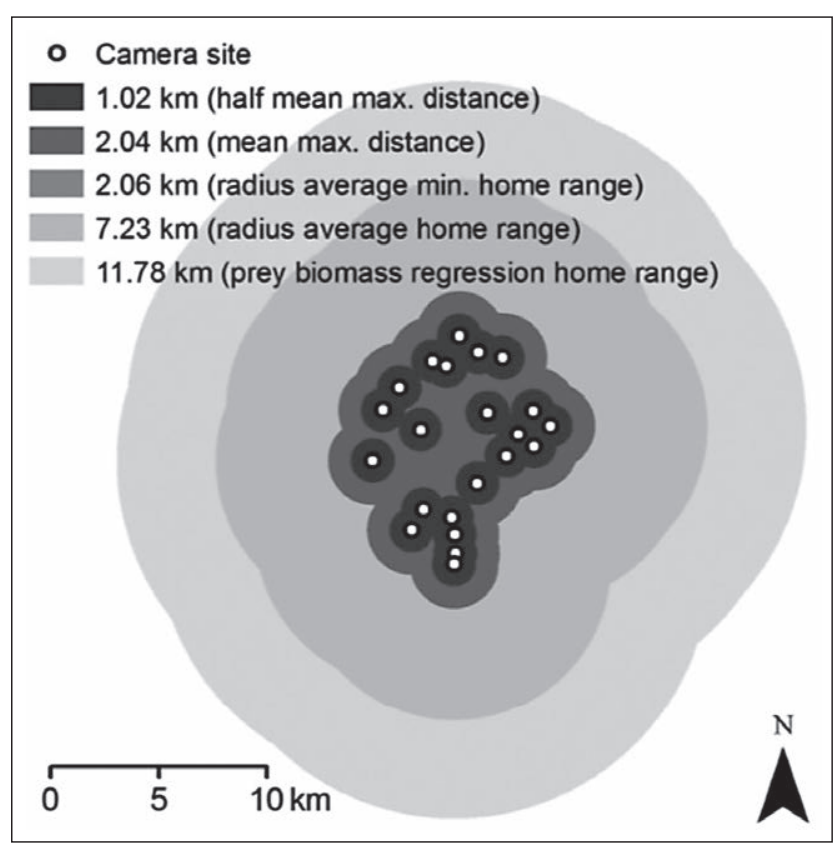

Fig. 1 Effective snow leopard study-area buffers around camera-trap sites in the Jangart huting reserve, Kyrgyzstan, 2005 (Source: McCarthy et al. 2008). methods, the density estimates can be altered considerably (McCarthy et al. 2008). Total area covered by cameras and size of the effective area of buffer circles are used for density calculations (McCarthy et al. 2008).

\section{Biotelemetry (Global Positioning System, Collaring and Radio Collaring)}

Biotelemetry is a method for obtaining detailed information about animals that are not easily observed (Jackson et al. 2004). Thanks to biotelemetry, it is possible to better understand the patterns of movement and factors affecting the distributions of animals, their home range, patterns of habitat utilization, social organization and habitat preferences (Jackson 1996; Schofield et al. 2007). This knowledge is important for behavioural ecology and the management and conservation of protected areas (Schofield et al. 2007). For snow leopard tracking, radio and satellite transmitters (Global Positioning System, GPS) are used. Both methods are based on receiving data or signals from the transmitter attached to a collar around the animal's neck.

For fitting the collar, the animal must be trapped, which requires special skills and can sometimes be dangerous for the animal, therefore both these methods are considered to be invasive (Jackson 1996; Jackson et al. 2004). According to Jackson (1996) the most effective trapping locations are places where vegetation, boulders and other physical structures constrain the movement of snow leopards to a natural trail less than $0.5 \mathrm{~m}$ wide and where an abundance of fresh snow leopard scrapes and related signs indicate recent visits and ongoing marking activity. The immobilized animals are usually weighed, measured, tattooed inside one ear with an identifying number and fitted with a radio-collar (Jackson 1996).

Telemetry is about one order of magnitude more costly than camera trapping due to the manpower and equipment needed (Jackson et al. 2004). Their use is often forbidden along national borders and in other politically sensitive areas, which coincide with a large proportion of the snow leopard's range (Schofield et al. 2007).

Radio tracking is based on the transmission of pulses of radio frequency by radar systems and measuring the time that they take to be reflected back (McEwan 1995). This time is a measure of the distance from the radar unit to the reflecting objects (McEwan 1995). Highly directional antennas allow such transmissions and signal reflections back to be narrowly focused, so that the direction of such reflective objects can also be estimated (McEwan 1995). Radio telemetry has been used in several parts of Nepal (Oli 1994), India (Chundawat 1989, 1990, 1992) and Mongolia (Schaller et al. 1994). Results of these studies are limited by small sample size (1-3 individuals) or periods of monitoring that never last longer than 3 months (Jackson et al. 2004). First in-depth study using radio telemetry was conducted by Rodney Jackson in Nepal in the 1980s. During 1994-1997, McCarthy et al. (2005) surveyed snow leopard movements and ac- 
tivities on the basis of year-round radio-monitoring in the Altai Mountains in southwestern Mongolia. Home ranges were determined to be at least of $13-11 \mathrm{~km}^{2}$ in size (McCarthy et al. 2005). The disadvantage of this method is that a mountainous, rocky terrain may affect radio-wave propagation and the range of reception due to radio-wave attenuation, signal bounce and deflection (Amlaner and MacDonald 1980; Jackson 1996).

Nowadays, the GPS method is used more frequently than radio telemetry due to its greater accuracy. By matching the animal's GPS coordinates with a habitat map using satellite images or aerial photographs and ground-truthing, the researcher is able to determine habitat features or conditions that are most important for feeding, resting or breeding (Jackson et al. 2004). Along with data on average home range size and prey densities, scientists are able to better estimate snow leopard population size and density (Jackson et al. 2004). In 2013 in Mongolia, for the first time ever a mother snow leopard and its cubs were located using GPS collars and remote camera traps (Noras 2015). The Snow Leopard Trust team collared a female snow leopard and its sub-adult offspring and thanks to that it is possible to monitor the movement of the mother and cub, and observe when and how the young cat becomes independent (Noras 2015).

\section{Comparison of the Methods Used for Estimating the Population Density of Snow Leopards}

For a rigorous comparison of the abundance of snow leopards it is important to obtain data for all of its habitats. Such data does not exist. Studies conducted in different snow leopard habitats are not methodologically consistent. The reasons may be objective, e.g., differences between habitats can cause difficulties in collecting data, or the differences in snow leopard densities may not allow the use of the same method. At high densities (4-8 individuals $/ 100 \mathrm{~km}^{2}$ ), lower standard errors and an area that can be studied for a long period of time make it feasible to use the camera capture-recapture method as in the Hemis National Park, India (Jackson et al. 2006; McCarthy et al. 2008). In areas with very low densities and little prior knowledge of snow leopard behaviour, it may prove impossible to obtain sufficient data for viable capture-recapture modelling within a short (usually about the 7-weeks) time frame (Karanth et al. 2002; McCarthy et al. 2008). This leads us to suggest that the camera capture-recapture method is unreliable, when used where home ranges fluctuate in size and the capture rate very low (McCarthy et al. 2008). Biotelemetry is also a valuable method for obtaining detailed information on the spatial dynamics of individuals. Nowadays, it is more usual to use GPS collars than radio collars, which are less reliable. However, a huge problem with GPS tracking is its very high price and logistic challenges. From this point of view, use of this method is only possible in countries with a high per capita income or with external support from international organizations.
When an exact determination of the densities is not needed, it is possible to use sign surveys or photo rates. According to McCarthy et al. (2008) these two methods provide a valid index of snow leopard abundance because of their similarity with genetic results. On the contrary, the estimates resulting from predator : prey biomass ratios and capture-recapture disagree with other estimates of abundance. For obtaining exact estimates of densities, it would be more appropriate to use non-invasive genetic analyses, as mentioned above. Their results are not subject to observer bias, as are other methods, for instance erroneous identification of scats. For example in the genetic study by Janecka et al. (2008) in Mongolia, up to 60\% of all scats that were attributed to snow leopard in fact belonged to red fox (Vulpes vulpes). From my point of view, the best way of estimating snow leopard abundance is by comparing the results of sign surveys with those of other methods (predator : prey biomass ratios, genetic analyses, camera trapping and camera capture-recapture).

\section{Worldwide Distribution}

Snow leopards are restricted to sub-alpine regions in South and Central Asia in a total of 12 countries (Fig. 2): China, Bhutan, Nepal, India, Pakistan, Afghanistan, Tajikistan, Uzbekistan, Kyrgyzstan, Kazakhstan, Russia and Mongolia (McCarthy and Chapron 2003). The total size of its habitat is approximately $1,835,000 \mathrm{~km}^{2}$ and the total population is between $4,510-7,350$ individuals (Fox 1994). Based on the range-wide model (Fig. 3) it's area of distribution is potentially larger: $3,024,728 \mathrm{~km}^{2}$ (McCarthy and Chapron 2003). This may be an over estimate, however, because the range-wide model only uses the geographic habitat and neglects other parameters such

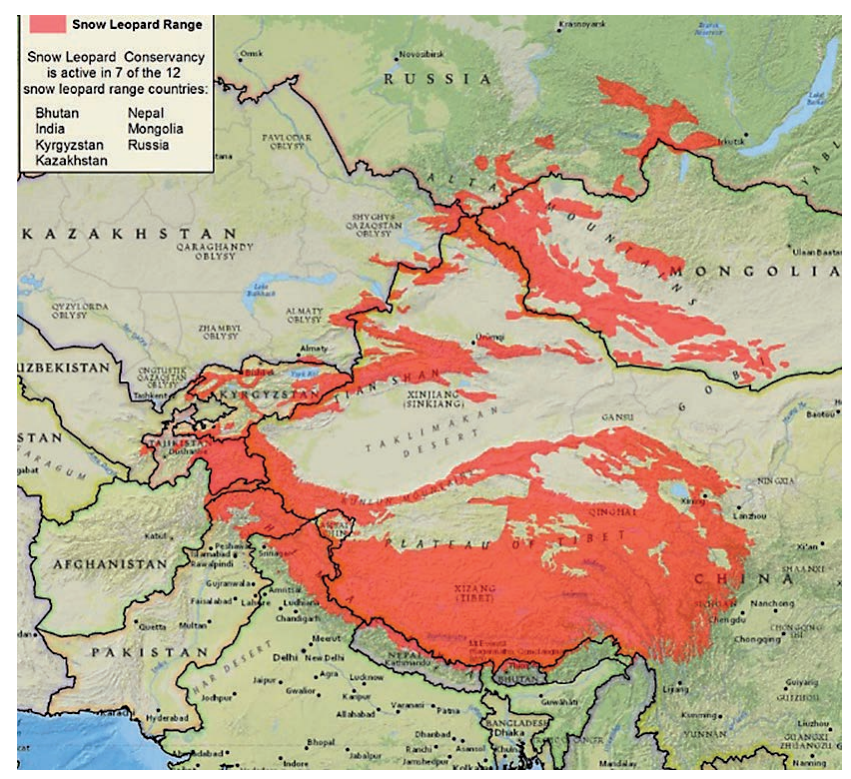

Fig. 2 Map showing the extent of the distribution of snow leopards (Source: Jackson et al. 2004). 


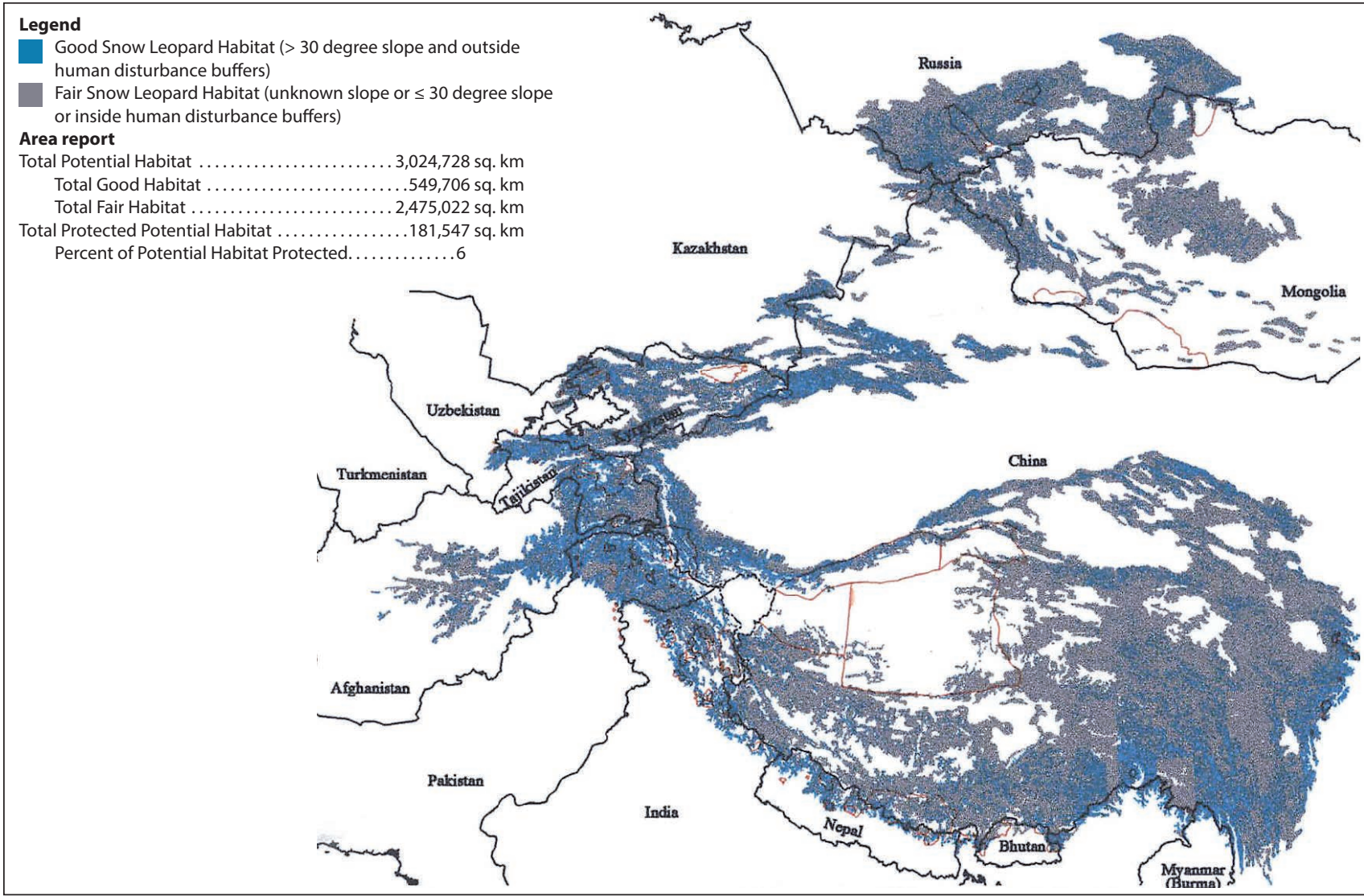

Fig. 3 Range wide model of potential snow leopard habitat (Source: McCarthy and Chapron 2003).

Table 3 Distribution, population estimates and population density of snow leopards (Source: Schaller 1976; Schaller 1977; Green 1988; Chundawat et al. 1988; Koshkarev 1989; Annenkov 1990; Jackson and Ahlborn 1990; Schaller 1990; Zhirjakov 1990; Fox et al. 1991; Jackson 1992; Schaller et al. 1994; Hunter and Jackson 1997; Jackson and Fox 1997b; Koshkarev 2000; McCarthy 2000a; Bykova et al. 2002; KreuzbergMukhina et al. 2002; Poyarkov and Subbotin 2002; Hussain 2003; McCarthy and Chapron 2003).

\begin{tabular}{|c|c|c|c|}
\hline Locality & $\begin{array}{c}\text { Area of } \\
\text { habitat }\left(\mathbf{k m}^{2}\right)\end{array}$ & $\begin{array}{l}\text { Estimated } \\
\text { population }\end{array}$ & $\begin{array}{l}\text { Population density } \\
\text { of snow leopards } \\
\text { (individuals/area) }\end{array}$ \\
\hline China & $1,100,000$ & $2,000-2,500$ & $\begin{aligned} & 1 / 250-300 \mathrm{~km}^{2} \\
\doteq & 0.3-0.4 / 100 \mathrm{~km}^{2}\end{aligned}$ \\
\hline Mongolia & 101,000 & $500-1,000$ & $?$ \\
\hline Nepal & 30,000 & $300-500$ & $0.1-10 / 100 \mathrm{~km}^{2}$ \\
\hline India & 75,000 & $200-600$ & $\begin{aligned} & 1 / 110-190 \mathrm{~km}^{2} \\
\doteq & 0.5-0.9 / 100 \mathrm{~km}^{2}\end{aligned}$ \\
\hline Pakistan & 80,000 & $200-420$ & $\begin{aligned} & 1 / 250 \mathrm{~km}^{2} \\
\doteq & 0.4 / 100 \mathrm{~km}^{2}\end{aligned}$ \\
\hline Tajikistan & 100,000 & $180-220$ & $?$ \\
\hline Kazakhstan & 71,079 & $180-200$ & $?$ \\
\hline Kyrgyzstan & 105,000 & $150-500$ & $2.35 / 100 \mathrm{~km}^{2}$ \\
\hline Russia & 130,000 & $150-200$ & $?$ \\
\hline Bhutan & 15,000 & $100-200$ & $1 / 100 \mathrm{~km}^{2}$ \\
\hline Afghanistan & 50,000 & $100-200$ & $?$ \\
\hline Uzbekistan & 10,000 & $20-50$ & $?$ \\
\hline
\end{tabular}

as competition, distribution of prey and grazing pressure (McCarthy and Chapron 2003).

Results of the range-wide model are presented in Fig. 3. Blue coloured areas are "good" sites with more than 30 degree slopes outside areas subject to human disturbance. Violet coloured areas are "fair" sites of unknown slope or less than 30 degrees or inside areas subject to human disturbance. Population densities of snow leopard in "good" areas are greater because they have a strong preference for irregular slopes in excess of $40^{\circ}(\mathrm{McCa}$ rthy and Chapron 2003). The 109 protected areas with total size of $276,123 \mathrm{~km}^{2}$, identified by Green and Zhimbiev (1997), are marked in red in Fig. 3. Table 3 shows estimated areas of snow leopard habitat in $\mathrm{km}^{2}$ and the estimated populations and densities for individual countries. Table 3 contains all the information that I was able to find, nevertheless some data are missing. According to Table 3, the largest populations of snow leopard are in China (2,000-2,500 individuals), Mongolia (500-1,000 individuals), Nepal (300-500 individuals) and India with 200-600 individuals. The greatest population density of snow leopards is in Nepal $\left(0.1-10 / 100 \mathrm{~km}^{2}\right)$, Kyrgyzstan $\left(2.35 / 100 \mathrm{~km}^{2}\right)$ and India $\left(0.5-0.9 / 100 \mathrm{~km}^{2}\right)$. Although the area of snow leopard habitat in Bhutan is the lowest $\left(15,000 \mathrm{~km}^{2}\right)$, the population density of snow leopards there is considerable $\left(1 / 100 \mathrm{~km}^{2}\right)$. There is an urgent need to determine the exact population density of snow 
leopards in Mongolia, Tajikistan, Kazakhstan, Russia, Afghanistan and Uzbekistan.

\section{Nepal, India, Bhutan, (Myanmar)}

The population of snow leopards in Nepal is estimated to be 150-300 individuals (Jackson 1979, unpub. data). However, a computerized habitat suitability model (Jackson and Ahlborn 1990) predicts a population of about 350 to 500 animals located in an area of approximately $30,000 \mathrm{~km}^{2}$ (Table 3, McCarthy and Chapron 2003). The largest populations occur in the western parts of Nepal: Mustang, Mugu, Dolpo and Humla districts (Jackson 1979). The population density of snow leopards in Nepal (0.1-10 individuals $/ 100 \mathrm{~km}^{2}$, Table 3 ) is one of the highest ones in the world. For instance, in the Langu Valley in western Nepal, it is $8-10$ individuals/100 km² (Jackson and Ahlborn 1989). Nepalese Himalayas are a good habitat for both snow leopard and its most important species of prey, blue sheep (Oli and Rogers 1991; Oli et al. 1993; Lovari et al. 2009; Aryal et al. 2010a).

Table 4 provides estimates of the numbers of animals monitored, number of days monitored, mean homerange size and ungulate population density for a few countries (India, Nepal and Mongolia). The exact size and shape of the home range of snow leopard in Nepal is not well known. The sizes of the home ranges of five individuals in Nepal range from 12 to $39 \mathrm{~km}^{2}$ (Table 4) and they overlap each other (McCarthy and Chapron 2003). This home range size is larger than, e.g., in Mongolia, where the terrain is more open and prey is less abundant than in Nepal (Table 4, 140-400 km²/individual).

Jackson and Ahlborn (1990) suggest that it is likely that a large proportion of Nepalese snow leopards live outside protected areas, where they are at greater risk of interacting with humans. A study carried out in Nepal indicates that $42-60 \%$ of the use of the home range oc-

Table 4 Estimates of snow leopard home-ranges $\left(\mathrm{km}^{2}\right)$ and related ungulate population density $\left(\mathrm{no} . / \mathrm{km}^{2}\right)$ reported in published studies for India 1990, Mongolia 1992, 2005, Nepal 1994, 1996, 1997 (Source: McCarthy et al. 2008).

\begin{tabular}{|l|c|c|c|c|l|}
\hline Location & No. animals monitored & No. days monitored & Mean home-range size & Ungulate population density & References \\
\hline India & 1 & 70 & 19.0 & $3.0-3.5$ & Chundawat 1990 \\
\hline Mongolia & 1 & 41 & 12.0 & $1.7-2.3$ & Schaller et al. 1992 \\
\hline Nepal & 3 & Winter & 19.0 & $6.6-10.2$ & Oli 1994, 1997 \\
\hline Nepal & 5 & $120-450$ & 19.4 & $4-8$ & Jackson et al. 1989 \\
\hline Mongolia & 4 & 207 & 451.0 & 0.9 & McCarthy et al. 2005 \\
\hline
\end{tabular}

Table 5 Methods used and the estimates of snow leopard abundance obtained

\begin{tabular}{|c|c|c|c|c|c|c|}
\hline Locality & $\begin{array}{l}\text { Sign survey } \\
\text { (all signs/km), } \\
\text { (scrapes/km) }\end{array}$ & $\begin{array}{l}\text { Genetic analy- } \\
\text { ses (minimum } \\
\text { population } \\
\text { size) }\end{array}$ & $\begin{array}{l}\text { Predator: prey } \\
\text { biomass ratios } \\
\text { (snow leopard/ } \\
100 \mathrm{~km}^{2} \text { ) }\end{array}$ & $\begin{array}{l}\text { Photo- } \\
\text { capture rates } \\
\text { (photos } / 100 \\
\text { trap nights) }\end{array}$ & $\begin{array}{l}\text { Total carrying } \\
\text { capacity (total } \\
\text { number of snow } \\
\text { leopards } / \mathbf{k m}^{2} \text { ) }\end{array}$ & $\begin{array}{l}\text { Photo capture- } \\
\text { recapture (snow } \\
\text { leopards } / 100 \text { km}^{2} \text {, } \\
\mathrm{n}=\text { identified s.l./ } \\
\text { photo) }\end{array}$ \\
\hline Mustang region, Nepal & $5.8,3.7$ & & 1.6 & 2.3 & $19,1.6 / \mathrm{km}^{2}$ & \\
\hline Mt. Everest, Nepal & $4.5,3.2$ & 4 & & & & \\
\hline Langu Valley, Nepal & 3.6 all signs/km & & & & & \\
\hline Rolwaling, Nepal & $3.2,<1$ & & & & & \\
\hline northern Pakistan & 2.4 all signs/km & & & & & \\
\hline Tomur, China & & 9 & 1.1 & 2.37 & & $0.74(n=5 / 6)$ \\
\hline Zongjia Township, China & & 11 & & & & \\
\hline $\begin{array}{l}\text { Nuimuhong Township, } \\
\text { China }\end{array}$ & & 5 & & & & \\
\hline Suojia Township, China & & 5 & & & & \\
\hline $\begin{array}{l}\text { Qilianshan Nature Reserve } \\
\text { of Gansu Province, China }\end{array}$ & & & & & & 3.52 \\
\hline Kunlun Mountains, China & $0.16,0.13$ & & & & & \\
\hline Sary Chat, Kyrgystan & & 3 & 8.7 & 0.09 & & $0.15(n=1 / 1)$ \\
\hline Jangart, Kyrgyzstan & & 5 & 1.0 & 0.93 & & $0.87(n=4 / 13)$ \\
\hline Hemis NP, India & & & & $8.9,5.6$ & & \\
\hline Khangchendzonga BR, India & & & & $0.257 \pm 0.16$ & & \\
\hline
\end{tabular}


curs within only $14-23 \%$ of the animal's total home area, indicating strong preference particular core areas. Core areas are marked significantly more than non-core areas, which indicates that social marking plays an important role in spacing out individuals (Jackson and Hunter 1996). The core zones in Nepal include Annapurna Conservation Area with approximately 350-500 snow leopards (Jackson and Ahlborn 1990). Almost the whole home range of snow leopards is surveyed for signs as mentioned above (Bikram Shrestha, pers. comm.). Sign density (Table 5) recorded at Mustang, which is in the Annapurna Conservation Area, is 5.8 signs $/ \mathrm{km}$, which includes 3.7 scrapes $/ \mathrm{km}$ (Ale 2007). These results are comparable for those reported for Mt. Everest (4.5 signs $/ \mathrm{km}, 3.2$. scrapes $/ \mathrm{km}$ ). Based on sign surveys, the highest abundance of snow leopards is in north-western Nepal in the Langu Valley with 36 signs $/ \mathrm{km}$. In the north-eastern part of Nepal at Rolwaling the sign density is lower (3.2. signs $/ \mathrm{km},<1$ scrape $/ \mathrm{km}$, Ale et al. 2010) than in the northwest. Sign density in Nepal is much higher than in northern Pakistan (2.4 signs/km, Hussain 2003) or Ladakh, India (2.6 scrapes/km, Fox et al. 2001). Based on genetic analyses (Table 5) 4 cats were detected in the Mt. Everest region in 2004-2006 (Lovari et al. 2009), which corresponds to the results from camera trapping, which indicate a minimum number of three individuals (capture rate; 2.3 individuals/100 camera trap nights) at Lower Mustang. Even though the sign density at Rolwaling is much lower than in Mt. Everest region, an unpublished report based on genotyping revealed occurrence there of three snow leopards (Karmacharya et al. 2012). In the upper Mustang region Aryal et al. (2014) estimate the biomass of blue sheep to be about $38,925 \mathrm{~kg}$, which could support roughly 19 snow leopards (Table 5, 1.6 snow leopards $/ 100 \mathrm{~km}^{2}$ ).

Charles University in Prague also participates in data collecting on snow leopard in Nepal. In Prague, Pavel Hulva, Dušan Romportl, Tereza Marešová, Pavel Kindlmann and Bikram Shrestha, who is collecting data in $\mathrm{Ne}$ pal, are cooperating. Shrestha et al. use genetic analyses and camera trapping. Shrestha has been studying snow leopards since 2004 in the Sagarmatha National Park in eastern Nepal and from 2010 to 2016 in the Annapurna Conservation Area, specifically in Lower Mustang and Upper Manang (Bikram Shrestha, pers. comm.). For camera trapping, the Bushnell model is used to estimate population size at different locations, identify individual snow leopards and determine gender. Although almost the whole Nepal is covered by sign surveys, a few areas lack detailed surveys. To obtain more exact information on the abundance of snow leopard, it would be appropriate to conduct surveys in those areas (e.g., Annapurna Base Camp), where prey is sufficiently abundant to support the presence of snow leopards.

Estimated population size of snow leopard in India is about 200-600 individuals in an area of 75,000 km² (Table 3, Chundawat et al. 1988; Fox et al. 1991). Counts of snow leopards are derived from an average density of one animal $/ 110 \mathrm{~km}^{2}$ for good habitat along the north slopes of the Himalaya with area of $30,000 \mathrm{~km}^{2}$ and one ani$\mathrm{mal} / 190 \mathrm{~km}^{2}$ for lower quality habitat along the southern slopes of Himalaya with area of $22,000 \mathrm{~km}^{2}$ (Table 3, Fox et al. 1991). Chundawat et al. (1988) suggested Ladakh as a core area of snow leopard $\left(72,000 \mathrm{~km}^{2}\right)$. Snow leopard may occur in the following protected areas: Himachal Pradesh State (e.g., Pin Valley National Park, Khokhan Wildlife Sanctuary or Rupi Bhaba Wildlife Sanctuary), Uttaranchal State (e.g., Nanda Devi National Park, Nanda Devi National Park or Yamunotri Wildlife Sanctuar), Arunachal Pradesh State (e.g., Dibang Valley), Sikkim State (e.g., Kangchendzonga National Park, Dzongri Wildlife Sanctuary, and Tolung Wildlife Sanctuary) and Jammu and Kashmir State with 12 areas (e.g., Hemis National Park, Dachigam National Park or Lungnag Wildlife Sanctuary). The presence of snow leopard in many of these areas is uncertain (McCarthy and Chapron 2003). Northwest India hosts approximately 400 snow leopards with largest densities in the trans-Himalayan ranges in Ladakh. Therefore, new parks and reserves are being established there (Fox et al. 1991). The only one protected area where the density of snow leopard is known is the Hemis National Park of Ladakh region located in the Jammu and Kashmir State. Mallon and Bacha (1989) estimated $75-120$ snow leopards in a $1,200 \mathrm{~km}^{2}$ area to be living there. Jackson et al. (2006) reported 66 and 49 capture events (capture success 8.9 and 5.6 per 100 trap-nights, Table 5) in two consecutive years of 2003 and 2004 in the Hemis National Park. In the Khangchendzonga Biosphere Reserve in the eastern Himalayan region (Sikkim), Sathyakumar et al. (2011) conducted the first survey to obtain basic information on abundance of mammals including snow leopard. They proved the presence of snow leopard based on photo capture, scat/dung, tracking and information from locals. Photo capture rate of snow leopard was 0.257 photos/100 trap nights (Table 5, Sathyakumar et al. 2011). Sathyakumar et al. (2011) recommend that surveys are also carried out in other watersheds of the Khangchendzonga BR. In India, it is necessary to cover the whole area by sign surveys and after that also conduct detailed studies.

In northern Bhutan, along the high Himalayas, in accord with area-based estimates, the confirmed presence of snow leopard is about 100-200 individuals (Table 3, Fox 1989). The density of snow leopard is assumed to be $1 / 100 \mathrm{~km}^{2}$. The suitable habitats are above $3,000 \mathrm{~m}$ in an area of about 15,000 km² (Fox 1994). In Jirgme Dorje National Park, sign surveys were conducted, suggesting a lower occurrence of snow leopards than in adjacent Shey Phoksundo National Park in Nepal, although there is a larger abundance of its prey in the former (Jackson and Fox 1997b; Jackson et al. 2000). In a part of the protected area (Torsa Strict Nature Reserve, Kulong Chhu Wildlife Sanctuary, Sakteng Wildlife Sanctuary) the occurrence of snow leopard is still not confirmed. 


\section{China and the Former Soviet Union}

China, the largest state where snow leopard occurs, contains as much as $60 \%$ of its potential habitat: about 1,824,316 km² (Fig. 3, Hunter and Jackson 1997; McCarthy and Chapron 2003). Area of snow leopard presence is estimated as $1,100,000 \mathrm{~km}^{2}$ with approximately 2,0002,500 individuals (Table 3, Fox 1994). Due to irregular distribution of its prey, the mean density is 1 snow leopard/250-300 km² (Table 3, McCarthy and Chapron 2003).

Snow leopard habitat is located in six provinces in China (Qinghai, Gansu, Sichuan, Yunnan, Xinjiang and Xizang or Tibet) and in the seventh one (Inner Mongolia) it is nearly extinct (McCarthy and Chapron 2003). In almost every province, there is a lack of status surveys, such as in Sichuan Provence, Yunnan Province and in Tibet Autonomous Region (TAR). In the TAR, at several sites blue sheep are abundant. Areas with the highest priority for status surveys are the Nayainqentanglha, Taniantaweng and Ningjing Shan mountains in eastern and south-eastern Tibet, western Nepal, the mountains bordering Uttar Pradesh in India and the Nganlang Kangri mountains bordering Ladakh (McCarthy and Chapron 2003). Snow leopards are likely to occur on the northern slopes of the Himalayas close to border with Nepal and on mountain ranges bisecting the Tibetan Plateau (McCarthy and Chapron 2003). Jackson (1994a) report up to 100 snow leopards in the Qomolangma Nature Preserve, a $33,910 \mathrm{~km}^{2}$ area along the main Himalayan and Nepalese border, centered around Mt. Everest. In the area including the Sanjiangyuan National Nature Reserve (Qinghai Province), Qiangtang National Nature Reserve (TAR) and Nanshan area (Danghe, Gansu Province) 89

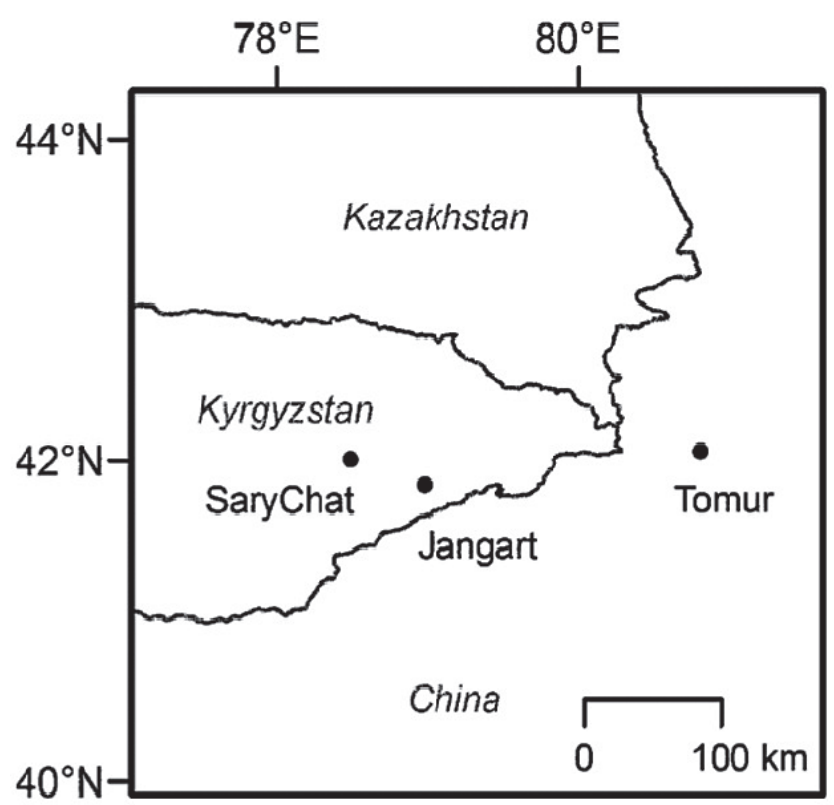

Fig. 4 Diagram of the study area showing the locations of 3 snow leopard camera capture-recapture study sites, Sary Chat, Jangart and Tomur, in the Tien Shan Mountains in Kyrgyzstan and China, 2005 (Source: McCarthy et al. 2008). samples were identified as indicating snow leopard and the presence of 48 individuals (Zhou et al. 2014). In the Tomur National Nature Reserve (Figure 4) in Xinjiang Autonomous Region there have been 20 SLIMS sign surveys (McCarthy et al. 2008). By counting the snow leopard's prey, ibex and argali, the snow leopard potential density was estimated to be 1.1 snow leopards $/ 100 \mathrm{~km}^{2}$ (Table 5, McCarthy et. al. 2008). Photo-capture rates in Tomur were 2.37 photos/100 trap-nights (Table 5). According to the results of the photo capture-recapture method ( 0.74 individuals $\left./ 100 \mathrm{~km}^{2}, \mathrm{n}=5 / 6\right)$, it is estimated that about 6 snow leopards occur in Tomur, whereas the genetic analyses indicates at least 9 individuals (McCarthy et al. 2008). Home range of snow leopard in the Qinghai Province is highly fragmented (Liao 1994). Zhang et al. (2009) identified 11, 5 and 5 (Table 5) snow leopards using genetic analyses in Zongjia Township (ZJ) and Nuomuhong Township (NMH) in Dulan County, and Suojia Township (SJ) in Zhiduo County, respectively.

Apart from these areas with snow leopard occurrence, Schaller et al. (2008) identified three "hotspots" in Qinghai Province: North Zadoi, South Zadoi and Yushe, where the population density of snow leopard was estimated to be 1 individual per $25-35 \mathrm{~km}^{2}$. In adjacent Gansu Provence northeast from Qinghai Province, 17-19 individuals were identified using the camera capture-recapture method. In total, 251 snow leopard captures were recorded over the 7,133 trap-days, which is an average of 3.52 captures per 100 trap-days (Table 5, Alexander et al. 2016).

The Gouli Region (Fig. 5), also in Qinghai Province, is considered to be one of the core zones of snow leopard in China. Sign surveys conducted there along transects of total length of approximately $440 \mathrm{~km}$, recorded 72 signs and 60 snow leopard scrapes ( $\mathrm{Xu}$ et al. 2008), which is 0.16 signs $/ \mathrm{km}$ and 0.13 scrapes $/ \mathrm{km}$ (Table 5). As mentioned there is no information on on the abundance of snow leopards in China and results of the few studies carried out there are not consistent with those from other countries.

Before the breakup of the USSR (1990) it was reported that there were 1,000 to 2,000 snow leopards there (Braden 1982; Bannikov 1984). Most of them (75\%) were in Kyrgyzstan and Tajikistan (Koshkarev and Vyrypaev 2000). According to these authors and Bannikov (1984), there were 150-200 snow leopards in the Russian Union Republic, 100 in Uzbekistan and 180-200 in Kazakhstan, making a total of about 2,000 individuals. Koshkarev (1989) estimates the population in Tien Shan and Dzhungarsky Alatau to be about 400-500 individuals. After the disintegration of the USSR, the populations in Kazachstan and Kyrgyzstan decreased by at least $50 \%$ due to poaching of snow leopards and ungulates (McCarthy and Chapron 2003). The current legal and management status of many reserves is unknown.

Snow leopards are reported in Russia (Table 3, Table 6, Fig. 2) in the Altai and Sayan ranges on the border with 


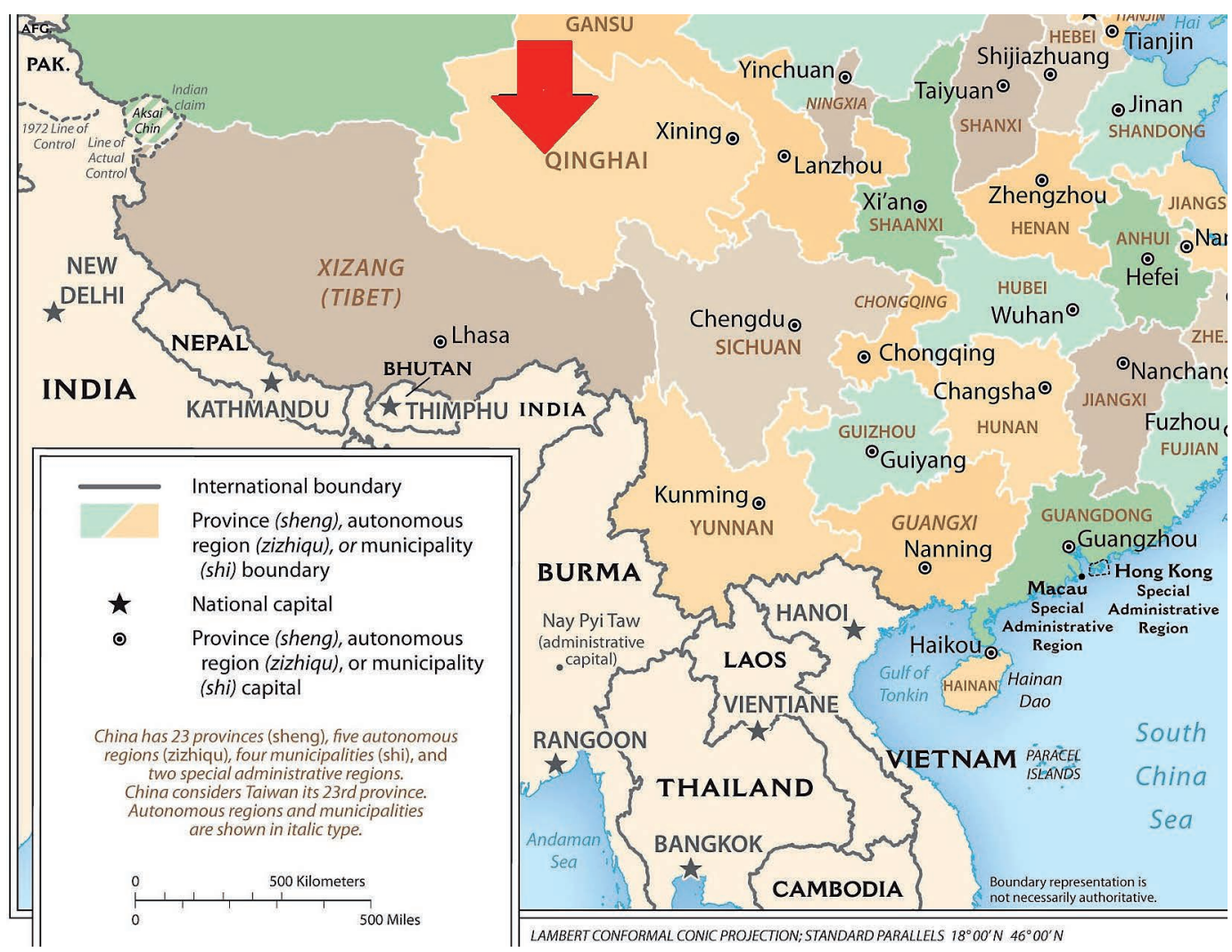

Fig. 5 Map showing the area surveyed in the Gouli Region in East Burhanbuda Mountain, Kunlun Mountains, China, and indicating the locations of leopard signs and camera traps (Source: Xu et al. 2008).

the People's Republic of Mongolia, and in southern Siberia, including the Tuvan and Buryat mountain ranges (Paltsyn et al. 2012). The mean population density in the Altai Mountains is estimated as $0.75-1.5 / 100 \mathrm{~km}^{2}$ with approximately 40 individuals (Sopin 1977). In accordance with Table 5, in the Chikhachev Ridge located in the Altai Republic, Tuva Republic and Mongolia, about 5-7 snow leopards occur, or 10-15 if we include those in Mongolia. Snow leopard population size in the Sayan region is about 20-30 individuals (Koshkarev 1996) and in Sayano-Shushensky Nature Reserve in the Sayan region about 9-10 (Table 6). In southern Siberia, snow leopards possibly occur on the Okinsky and Tunkinsky Ridges (Table 6, Paltsyn et al. 2012). Smirnov et al. (1990) estimate that about 80 snow leopards reside in southern Siberia including animals that stray into Mongolia. As mentioned in Table 5, more research needs to be done in this area. In general for Russia, detailed data are lacking or outdated.

In Kyrgyzstan, there is insufficient information on wildlife in terms of the post-Soviet distribution and status of many species (McCarthy et al. 2010). On the other hand, the Government of the Kyrgyz Republic has increased the enforcement and development of protected areas (Dexel 2002; Chapron 2005). Snow leopards occur in the Talasskiy Alatau and Ferganskiy mountains and in Tien Shan bordering on China and Kazakhstan (Fig. 2, Braden 1982; Koshkarev 1989). Koshkarev (1989) estimates a population of 113-157, with an average popu- lation density of 2.35 snow leopards/ $100 \mathrm{~km}^{2}$ (Table 3). McCarthy et al. (2008) report snow leopard abundance at Jangart and Sary Chat Ertash in the Tien Shan Mountains in eastern Kyrgyzstan (Table 5). Sixteen sign surveys in the Sary Chat with total transect length of $8.2 \mathrm{~km}$ and 13 surveys with $8.6 \mathrm{~km}$ transect length in the Jangart revealed 7 snow leopards in the Jangart. According to photo capture-recapture 0.15 ( $\mathrm{n}=1$ identified individual/1 photograph) were recorded in the Sary Chat and 0.87 (n $=4 / 13$ ) in the Jangart (Table 5). By counting the snow leopard prey: ibex and argali, snow leopard potential density was estimated as 8.7 snow leopards $/ 100 \mathrm{~km}^{2}$ in Sary Chat and 1.0 snow leopard $/ 100 \mathrm{~km}^{2}$ in Jangart.

According to Hunter and Jackson (1997), the estimated size of potential snow leopard habitat in Kazakhstan is $71,079 \mathrm{~km}^{2}$. Its estimated population size is approximately 180-200 individuals (Table 3, Annenkov 1990; Zhirjakov 1990). In the south of Kazakhstan, snow leopards occur in the Khigizskiy Range and Tasskiy Alatau bordering Kyrgystan, in the Sarytau Mountains near Alma Ata and bordering China in the Dzungarsky Alatau (McCarthy and Chapron 2003). According to Zhirjakov (1990) there are about 20 snow leopards in Zailiskiy Alatau and northern Tien Shan. The presence of snow leopard in protected areas is confirmed for the Aksu Dzhabagliy State Reserve and Alma Atinskiy Nature Reserve ( $\mathrm{McCa}$ rthy and Chapron 2003).

There is no data on the current status and distribution of snow leopard in Tajikistan. They are said to occur 
Table 6 Habitat area of snow leopards and estimates of their abundance in Russia (Source: Paltsyn et al. 2012).

\begin{tabular}{|c|c|c|c|}
\hline Location & Habitat area, $\mathbf{k m}^{2}$ & $\begin{array}{l}\text { Estimate population } \\
\text { (\# of animals) }\end{array}$ & Notes \\
\hline Chikhachev Ridge & 1000 & $5-7$ & $\begin{array}{l}\text { Total population of this trans- } \\
\text { boundary group, including } \\
\text { Mongolia, is } 10-15 \text { animals }\end{array}$ \\
\hline $\begin{array}{l}\text { Tsagan-Shibetu Ridge, southern Shap- } \\
\text { shalsky Ridge, western side of Western } \\
\text { Tannu-Ola Ridge }\end{array}$ & 2500 & $15-18$ & $\begin{array}{l}\text { Total population of this trans- } \\
\text { boundary group, including } \\
\text { Mongolia, is } 20-25 \text { animals }\end{array}$ \\
\hline $\begin{array}{l}\text { Sayano-Shushensky Nature Reserve, } \\
\text { its buffer zone, and adjacent parts of } \\
\text { Khemchiksky and Kurturshubinsky Ridges }\end{array}$ & No more than $200-500$ & $9-10$ & \\
\hline Sengelen Ridge & 2000 & $7-10$ & \\
\hline Okinsky and Tunkinsky Ridges, possibly & $5000-6000$ & $15-20$ & $\begin{array}{l}\text { This area requires additional } \\
\text { research }\end{array}$ \\
\hline Total & $\begin{array}{l}6000 \text { (possibly } 11,000-12,000 \\
\text { if Okinsky and Tunkinsky } \\
\text { Ridges are included) }\end{array}$ & $\begin{array}{l}\text { 36-45 (possibly } 50-65 \text { if } \\
\text { Okinsky and Tunkinsky Ridge } \\
\text { populations are included) }\end{array}$ & \\
\hline
\end{tabular}

in the central and western parts in the Zeravshanskiy, Gissarskiy, Karateginskiy and Petr Pervyi mountains, in the Hazratishog and Darvaskiy Mountains and the Gorno-Badahshansk area, including the Pamirs (McCarthy and Chapron 2003). Bykova et al. (2002) estimate a total of 180-220 snow leopards occur there (Table 3). Occurrence of snow leopard is confirmed mainly in reserves and protected areas such as in the Great Pamir National Park (Hunter and Jackson 1997), Ramit State Reserve, Dashti-Dzhumskiy Reserve (Sokov 1990), Iskanderskul'skiy lake reserve, Muzkul'skiy, Pamisskiy and Sangvorskiy Zakazniki reserves (McCarthy and Chapron 2003). In 2003, Rodney Jackson conducted a survey in order to determine whether it was possible to promote wildlife conservation in Tajikistan. He trained local staff and herders to monitor snow leopards and Marco Polo sheep using basic survey methods based on transects (Jackson et al. 2004).

Uzbekistan is at the western edge of snow leopard's home range. They occur in the Turkestanskiy, Chatkalskiy and Gissarskiy ranges bordering Tajikistan and Kyrgyzstan (Braden 1982), where the total population is estimated to be 50 animals (Sludskiy 1973, cited in Braden 1982). Recently Kreuzberg-Mukhina et al. (2002) estimated the population of snow leopard to be about 20-50 in an area of 10,000 $\mathrm{km}^{2}$ (Table 3). As in Tajikistan, snow leopard presence is confirmed in protected areas, for instance in Zaaminskiy State Reserve, Uzbek National Park, Gissarskiy State Reserve and the Chatkal'skiy State Reserve (McCarthy and Chapron 2003).

\section{Pakistan, Afghanistan and Mongolia}

The potential snow leopard habitat in Pakistan covers $80,000 \mathrm{~km}^{2}$ (Table 3, Fox 1994) with about 200-420 individuals (Schaller 1977; Hussain 2003). Assuming a mean density of 1 snow leopard $/ 250 \mathrm{~km}^{2}$, the total number of snow leopards would be approximately 320 (McCarthy and Chapron 2003). Its occurrence is verified in the
Northwest Frontier Provinces, Chitral District and in the Karakorum Range in the Northern Areas in the Gilgit, Hunza and Baltistan districts (McCarthy and Chapron 2003). Hussain (2003) surveyed the Baltistan district between 1998 and 2001 and estimates that approximately 36-50 snow leopards live there. With respect to the availability of its prey and suitable habitat he suggests 90-120 snow leopards occur in the whole Baltistan. Its presence in Azad Kashmir Province remains unconfirmed (Roberts 1977). Snow leopard occurrence is confirmed in the following protected areas: North-West Frontier Province (Chitral Gol National Park, Agram Besti Game Reserve, Goleen Gol Game Reserve, Gahriat Gol Game Reserve) and in northern parts (Khunjerab National Park, Baltistan Wildlife Sanctuary, Kargah Wildlife Sanctuary, Nazbar Nallah Game Reserve). In many protected areas, there are potential habitats for snow leopard, but there presence there has not been verified: Parit Gol Game Reserve, Tirichmir and Qashqar Conservancies, Kilik/ Mintaka Game Reserve, Naz/Ghoro Game Reserve, Sherquillah Game Reserve, Askor Nullah Game Reserve, Astore Wildlife Sanctuary, Chassi/Bowshdar Game Reserve, Danyor Nallah Game Reserve, Pakora Game Reserve, Machiara National Park and Ghamot Game Reserve (McCarthy and Chapron 2003). Snow leopards are also likely to be present in the Nanga Parbat Conservancy (McCarthy and Chapron 2003).

The numbers of snow leopards in Afghanistan remain to be determined. The estimates of the area of potential habitat in Afghanistan differ from each other. Fox (1989) estimates $80,000 \mathrm{~km}^{2}$ and subsequently $50,000 \mathrm{~km}^{2}$ (Fox 1994), and Hunter and Jackson (1997) suggest 117,653 $\mathrm{km}^{2}$ (Table 3). Snow leopard occurrence is confirmed in the Hindu Kush and Pamir mountains in north-eastern Afghanistan (Habibi 1977; Petocz 1978; Sayer 1980). Snow leopards occur at Zedak in the southern part of Badakhshan (McCarthy and Chapron 2003). Due to a long history of many wars in Afghanistan, wildlife laws 
are not enforced there (McCarthy and Chapron 2003). The actual status of snow leopards at many locations is unknown (McCarthy and Chapron 2003). The latest information on the occurrence of snow leopards in Wakhan District in Badakhshan, was obtained by the Wildlife Conservation Society (WCS) and National Environmental protection Agency who installed remote camera traps in 2009 and recorded over 1300 images of snow leopard at 20 sites (Noras 2015). Three individuals were captured and equipped with satellite collars in 2012. Thanks to the confirmation of the presence of snow leopards in that area, the whole of Wakhan Distict, with area of $10,000 \mathrm{~km}^{2}$, was declared a National park in 2014 (Noras 2015).

Mongolia is the state with the second largest population of snow leopards, estimated at 500-1,000 individuals in an area of approximately $101,000 \mathrm{~km}^{2}$ (Green 1988) (Table 3, Fig. 2, Schaller et al. 1994; McCarthy 2000). It occurs in at least 10 protected areas: the Transaltay Gobi Strictly Protected Area or SPA, Khokh Serkh SPA, Otgontenger SPA, Tsagaan Shuvuut SPA, Turgen Uul SPA, Gobi Gurvansaikhan National Conservation Park, Altai Tavaan Bogd NCP, The Burhan Buudai Nature Reserve, Alag Khairkhan Nature Reserve and Eej Uul National Monuments (McCarthy and Chapron 2003). The main populations occur in the Altay and Transaltai Gobi mountain ranges, with smaller populations in the Khangai, Hanhohiy Uul and Harkhyra Uul ranges (McCarthy and Chapron 2003). Bold and Dorzhzunduy (1976) estimate that there are 170-230 snow leopards in the southern Gobi region in Mongolia. During 1994-1997 McCarthy et al. (2005) recorded snow leopard movements and activities based on year-round radio-monitoring in the Altai Mountains kin south western Mongolia. Home ranges determined by standard telemetry techniques are at least of $11-13 \mathrm{~km}^{2}$ (McCarthy et al. 2005). In the area of Burhan Budai in the Altay, Schaller et al. (1994) found signs of at least 10 cats within $200 \mathrm{~km}^{2}$. This population density is one of the highest estimated in the whole of its habitat. From 2008, the Snow Leopard Trust (SLT) and Panthera, in co-operation with the Mongolian government, started a 10 year program. Hitherto they captured and radio collared 20 individuals. To date, in the Altai Mountains there are conservation programs involve more than 400 herder families (Noras 2015). In 2014 in Tsagaan Shuvuut Strictly Protected Areas, at a transboundary site in Mongolia and Russia, a Mongolian-Russian team, headed by Dr. B. Munkhtsog captured a female snow leopard and fitted her with a North star satellite collar provided by the Snow Leopard Conservancy.

\section{Conservation of Snow Leopard}

Conservation of snow leopard is a very complex problem because its habitat is very rugged, it has a large home range and frequently comes into conflict with humans (Li 2013). Below is a list of some possible ways of protect- ing it by means of legislation, international cooperation, financial support, education and awareness.

\section{Legislation}

Legislation relating to the conservation of snow leopards is based on the designation of nature reserves by governments and supporting programs led by nongovernmental organizations (McCarthy and Chapron 2003; Mishra et al. 2003). However, their abilities are limited (Li 2013). There is a little information on the current management status of protected areas or their role in sustaining snow leopard populations (Green 1992, 1994; Fox 1994; Green and Zhimbiev 1997). To date, the areas of snow leopard habitat covered by nature reserves are just $0.3-27 \%$ in 11 of 12 countries ( $\mathrm{Li} 2013$ ). The only exception is Bhutan with $57 \%$ of the area of snow leopard home range protected (Hunter and Jackson 1997).

To preclude the threats to snow leopard such as poaching and illegal trade, it is necessary to implement legislation and conservation policies and prevent the hunting, killing, possession, sale and trade in snow leopards including all its body parts and derivatives at local, regional and national levels (Theile 2003; Aryal et al. 2013). It would help if governments could be assisted and given advice on how to penalize people who break the law, and to consider implementing "whistle-blower" policies to provide incentives for report illegal activities (Theile 2003; Aryal et al. 2013). Theile (2003) also recommend the setting up of "antipoaching" teams, which would monitor main markets and trade centres in order obtain information on illegal killing. For a better understanding of the factors affecting the effectiveness of protected areas for the conservation of diversity, long-term and detailed research and the evaluation of the interactions between populations outside and inside protected areas are needed (Gaston et al. 2008).

For successful conservation it is important to have the support of the government in each state. Four countries already have national action plans: Nepal, Pakistan, Mongolia and Russia (McCarthy et al. 2003). The government of India initiated Project Snow Leopard (PSL), a national governmental program, on 20 January, 2009. The goal of that project is to conserve snow leopard together with other species living at high-altitudes in five states in the Himalayas: Jammu and Kashmir, Himachal Pradesh, Uttarakhan, Sikkim and Arunachal Pradesh (Rajput 2009). The PSL is based on knowledge-based adaptive wildlife management policies and actions, law enforcement and promotion of awareness, and education on wildlife conservation (Rajput 2009). The PSL was constructed at a national conference at Ladakh in 2006 thanks to the collaboration of the International Snow Leopard Trust (ISLT), the Nature Conservation Foundation (NCF), the State Governments, the Ministry of Environment and Forests (Government of India), Wildlife Institute of India (WII), the Snow Leopard Network, local communities and certain NGOs (Rajput 2009). 


\section{International Cooperation}

Snow leopard home range spans 12 countries in South and Central Asia. Therefore, cooperation of all these states is necessary, using internationally valid acts such as Convention on International Trade in Endangered Species of Wild Fauna and Flora (CITES), which regulates the export or import of animals or their body parts (Nowell 2007). Protected areas play an important role in sustaining the overall snow leopard population because the home range of snow leopards includes areas that constitute international borders (McCarthy and Chapron 2003). The Snow Leopard Network (SLN 2008) unifies individuals and organizations such as the Snow Leopard Conservancy and the International Snow Leopard Trust. The function of the SLN is to coordinate, cooperate and share information. International conferences try to identify locations for snow leopard conservation, name Snow Leopard Conservation Units and provide a framework for the development of national action plans (Jackson et al. 2008). Recently, e.g., an International Conference on Range-wide Conservation Planning for Snow Leopards was held in Beijing, China in March 2008. Another function of international societies, such as the World Wildlife Fund (WWF), is to secure with governments transparent and clear funding for compensatory programmes, for instance with the Nepalese government (Ikeda 2004).

Snow leopard is legally protected from hunting by national legislation in most of the 12 states in its home range (McCarthy et al. 2003). Afghanistan has recently afforded snow leopards legal protection, after listing this species on the country's first Protected Species List in 2009. This act bans all hunting and trading of snow leopards within Afghanistan. Except for Tajikistan, the rest of the countries are signatories to the CITES agreement (Jackson 2014).

\section{Education and Awareness}

It is important to educate and increase awareness of snow leopard conservation among local communities, national governments and international audiences (Jackson et al. 2008). The effectiveness of conservation management is increased by using community-based programs that involve local people such as livestock herders, trekking guides, farmers and former hunters (Sathyakumar et al. 2011). Various ways of supporting cultural, social and religious beliefs of locals exist such as education of the public by monks in monasteries or involving locals in some studies, e.g., measurement of changes in climate (Jackson et al. 2008).

The Snow Leopard Survival Strategy (McCarthy et al. 2003) may include the management of grazing in order to diminish its effect on native wildlife (e.g. large ungulates) and support for husbandry practices that reduce livestock vulnerability to snow leopard predation and improve efficiency and yield (Jackson et al. 2008). As mentioned above, herders of small and medium-sized livestock are notably vulnerable to losses of livestock, which can be reduced corralling the livestock at night. Understanding what determines the carrying capacity (based on the distribution and population structure) of predators such as snow leopard will simplify the management of the human-wildlife conflict (Aryal et al. 2014). One of the major issues is the protection of prey populations (e.g. blue sheep) as a resource for snow leopards in order to reduce their need to kill livestock and so inflame the human-predator conflict (Aryal et al. 2014). It is also appropriate to provide a legal mechanism, which enables herders to kill snow leopards that repeatedly kill their livestock (McCarthy and Chapron 2003). In prior studies, physical precautions, such as installation of predator-proof livestock corrals or guard dogs or formation of core areas, for snow leopard conservation were recommended (Jackson and Hunter 1996; McCarthy and Chapron 2003). Another issue is to decrease the suspicion of herders that snow leopard abundance will increase unduly in the future, by more adaptable conservation policies that provide a better compromise between livestock rearing and wildlife protection (Ikeda 2004).

One of the ways of protecting snow leopards is a monastery-based conservation. In the Sanjiangyuan region in China's Qinghai Province and Mustang in Nepal, Buddhist monasteries play an important role in snow leopard conservation ( $\mathrm{Li}$ 2013; Ale et al. 2014). This method may prove very efficient and by establishing it in other Tibetan Buddhist regions, it could result in the extension of protection to about $80 \%$ of the snow leopard habitat (Li 2013). It should be possible to decrease the killing of snow leopards by adhering to Buddhist tenets such as respect, love and compassion for all living beings. Thus, the 336 monasteries located in the Sanjiangyuan region could protect more snow leopard habitat $\left(8,342 \mathrm{~km}^{2}\right)$ through social norms and active patrols than the core zones of the nature reserves ( $\mathrm{Li} 2013$ ).

As mentioned above, climate change is another serious issue (Threats to the Snow Leopard - Climate change). It is important to implement strategies that mitigate and adapt conservation management at the local level in order to reduce the effect of climate change (Jackson et al. 2008). This strategy may include plantations on private land and in local areas, use of solar energy for cooking and heating, spread of the seeding of native grasses around the area, development of water holes in areas where long distances need to be covered, storage of rainfall water for agriculture, construction of reservoirs for winter and times of water shortage, control of poaching and continued monitoring of the distribution of trees (Aryal et al. 2013). For conservation planning, bioclimatic models, used to predict the persistence of species populations and habitats resulting from climate change, are impractical because their reliability and scope are limited (Heikkinen et al. 2006; Lawler et al. 2006). Therefore, the use of individual-species climate models as guidelines 
for climate-integrated conservation planning may be more appropriate. They are more reliable than community-based or assemblage models (Hannah et al. 2002a; Pearson and Dawson 2003; Thuiller 2007).

\section{Financial Support}

For efficient conservation it is essential to understand the economic situation of local herders and to find how to avoid conflicts between wildlife conservation and livestock rearing in countries where incomes are low (Ikeda 2004). It is necessary to obtain detailed ecological and socio-economic information in order to design a system, which will function successfully (Mishra et al. 2003). Except for the Annapurna Conservation Area and the Spiti Region in Himachal Pradesh in India, where these surveys were conducted by Oli et al. (1994), Jackson et al. (1996), and Mishra (1997), there is a lack of such data for the rest of the snow leopard habitat (Ikeda 2004).

One option for improving the compensatory mechanism, is to involve herders in ecotourism activities (Schellhom and Simmons 2000), as in Baltistan (Tibet) and Pakistan (Hussain 2000). This made not be possible in Nepal because of the unstable situation in the country due to the lack of foreign trekkers (Hussain 2000). Other alternative financial incentives recommended by the Snow Leopard Survival Strategy (McCarthy et al. 2003) are the establishment of cottage industries, e.g., village-made handicrafts, or a well-structured ungulate trophy hunting program (Mishra et al. 2003; Jackson et al. 2008). This innovative program is already operating in Kyrgyzstan (Mishra et al 2003; McCarthy et al. 2010)

\section{Conclusions}

In this review, I have summarized the distribution of snow leopard in each of the countries in which it occurs based on the estimates available (Table 3 and 5). Despite all efforts, it was impossible to compare results obtained by using different methods, mainly due to inconsistent results. According to my survey, the largest populations of snow leopard are in China (2,000-2,500 individuals), Mongolia (500-1,000 individuals), Nepal (300-500 individuals) and India with 200-600 individuals (Table 3). On the other hand, the smallest populations are in Russia (150-200), Bhutan (100-200), Afghanistan (100-200) and in Uzbekistan (20-50). Based on the available data, the greatest population density of snow leopard per $100 \mathrm{~km}^{2}$ of suitable habitat is in Nepal $\left(0.1-10 / 100 \mathrm{~km}^{2}\right)$, Kyrgyzstan $\left(2.35 / 100 \mathrm{~km}^{2}\right)$ and India $\left(0.5-0.9 / 100 \mathrm{~km}^{2}\right)$. Although the area of habitat in Bhutan is one of the lowest $\left(15,000 \mathrm{~km}^{2}\right)$, the population density of snow leopards there is very high $\left(1 / 100 \mathrm{~km}^{2}\right)$. There is a need to determine the population density of snow leopards in Mongolia, Tajikistan, Kazakhstan, Russia, Afghanistan and Uzbekistan.
In the section Comparison of Methods Used for Snow Leopard Density Estimation, I compared the use of different methods to estimate snow leopard abundance. From my point of view, the best way is first to carry out a survey of signs, which can serve as a pilot study for choosing the appropriate method(s) and then comparing the results of all the methods used with those of other methods (predator : prey biomass ratios, genetic analyses, camera trapping and camera capture-recapture methods).

I have analysed the general threats to snow leopards in various regions, which revealed that the main threats come from conflict with locals (human-snow leopard conflict), lack of a conservation capacity, illegal trade, poor awareness and policy, and climate change. Killing snow leopards for killing livestock and the decline in the abundance of their natural prey is inherently challenging in the Himalayan region (India, Nepal, Bhutan, Tibetan Plateau and southern China), Karakorum and Hindu Kush (southwest China, Pakistan and Afghanistan). The issue of military conflict is also a problem in the Himalayan region and Commonwealth of Independent States and western China.

In order to improve conservation management for increasing the likelihood of snow leopards surviving, it would be useful to obtain detailed information on the current management status and its role in sustaining snow leopard populations in protected areas for which such information is currently unavailable.

Introduction of "antipoaching" teams may decrease poaching and illegal trade in areas where snow leopards are present. To improve international cooperation, the signature of Tajikistan, the last non-signatory country, to the CITES agreement is needed. Also, trans-boundary cooperation should be increased in areas of the snow leopard home range in order to decrease logistic constraints, e.g. transport of samples for genetic analyses, or the building of more laboratories in each country. Action plans now exist only for Nepal, Pakistan, Mongolia and Russia. It would be advisable to create national action plans or governmental programs in the remaining countries.

Based on my survey, the most successful conservation is that based on community-based programs involving local people, such as monastery-based conservation, protecting snow leopard through the adoption of social norms and active patrols. Thus it may be effective to spread this method to other Tibetan Buddhist regions. To improve the financial aspect of conservation management of snow leopards, it is important to understand the economic situation of local herders (up to now this is only available for the Annapurna Conservation Area in Nepal and Spiti Region in Himachal Pradesh in India) and estimate the monetary value of damage to livestock in order to determine the correct level of compensation. It is also important to improve the procedure for verifying the damage to livestock caused by snow leopards. The compensatory system may involve, e.g., ecotourism or cottage industry. 
Another possible improvement to snow leopard conservation would be a decrease in the human-snow leopard conflict. One of the possible ways of doing this is to provide a legal mechanism by which herders can remove those snow leopards that persistently attack their livestock.

\section{REFERENCES}

Ale SB, Shrestha B, Jackson R (2014) On the status of Snow Leopard Panthera uncia (Schreber 1775) in Annapurna, Nepal. J Threat Taxa 6: 5534-5543. DOI http://dx.doi.org/10.11609 /JoTT.o3635.5534-43.

Alexander JS, Zhang Ch, Shi K, Riordan P (2016) A granular view of a snow leopard population using camera traps in Central China. Biol Conserv 197: 27-31.

Amlaner CJ, MacDonald DW (1980) A Handbook on Biotelemetry and Radio Tracking. Pergamon Press, Oxford.

Annenkov BP (1990) The snow leopard in the Dzungarsky Plateau. Int Pedigree Book Snow Leopards 6: 21-24.

Aryal A, Brunton D, Raubenheimer D (2013) Impact of climate change on human-wildlife-ecosystem interactions in the Trans-Himalaya region of Nepal. Theor Appl Climatol 115: 517-529. DOI 10.1007/s00704-013-0902-4.

Aryal A, Brunton D, Ji W, Raubenheimer D (2014) Blue sheep in the Annapurna Conservation Area, Nepal: habitat use, population biomass and their contribution to the carrying capacity of snow leopards. Integr Zool 9: 34-45. DOI 10.1111/1749-4877 .12004 .

Aryal A, Raubenheimer D, Ji W, Brunton D (2012b) Blue sheep and snow leopard: prey population density, distribution and habitat use of a principal prey species determines the carrying capacity for the predator. Integr Zool 9: 34-45.

Azlan JM, Sharma DSK (2006) The diversity and activity patterns of wild felids in a secondary forest in Peninsular Malaysia. Oryx 40: 36-41.

Bagchi S, Mishra C (2006) Living with large carnivores: predation on livestock by the snow leopard (Uncia uncia). J Zool 268: 217.

Bannikov AG (1984) Red Data Book of the USSR. Lesnaya Promyshlenhost Publishers, Moscow (in Russian).

Beaumont LJ, Pitman A, Perkins S, Zimmermann NE, Yoccoz NG, Thuiller W (2011) Impacts of climate change on the world's most exceptional ecoregions. P Natl Acad Sci 108: 2306-2311.

Bold A, Dorzhunduy S (1976) Report on snow leopards in the southern spurs of the Gobi Altai. Proc. Institute of General and Experimental Biology, Ulaanbaatar 11: 27-43 (in Russian).

Bowkett AE, Rover F, Marshall AR (2007) The use of camera-trap data to model habitat use by antelope species in the Udzungwa Mountain forests, Tanzania. Afr J Ecol 46: 479-487.

Braden KE (1982) The geographic distribution of snow leopards in the USSR: maps of areas of snow leopard habitation in the USSR. Int Pedigree Book Snow Leopards 3: 25-39.

Buzurukov A, Muratov R (1994) Snow leopards in Tajikistan. In: Fox JL, Jizeng D (eds) Proceedings of the Seventh International Snow Leopard Symposium (Xining, Qinghai, China, July 2530, 1992). International Snow Leopard Trust, Seattle, Washington, pp 29-32.

Bykova E, Grebot B, Kreuzberg-Mukhina E (2002) Assessment of the Snow Leopard in Central Asian region. Unpublished report.

Can OE, Togan I (2009) Camera trapping of large mammals in Yenice Forest, Turkey: Local information versus camera traps. Oryx 43: 427-430.
Carbone C, Gittleman JL (2002) A common rule for the scaling of carnivore density. Science 295: 2273-2276.

Carbone C, Christie S, Conforti K, Coulson T, Franklin N, Ginsberg JR, Griffiths M, Holden J, Kawanishi K, Kinnaird M, Laidlaw R, Lynam A, Macdonald DW, Martyr D, McDougal C, Nath L, O’Brien T, Seidensticker J, Smith DJL, Sunquist M, Tilson R, Wan Shahruddin WN (2001). The use of photographic rates to estimate densities of tigers and other cryptic mammals. Anim Conserv 4: 75-79.

Caughley G (1977) Analysis of Vertebrate Populations. Brisbane: John Wiley and Son.

Chapron G (2005) Re-wilding: Other projects help carnivores stay wild. Nature 437: 318.

Christensen M, Heilmann-Clausen J (2009) Forest biodiversity gradients and the human impact in Annapurna Conservation Area, Nepal. Biodivers Conserv 18: 2205-2221.

Chundawat RS, Rodgers WA, Panwar HS (1988) Status report on snow leopard in India. In: Freeman H (ed) Proceedings of the Fifth International Snow Leopard Symposium. International Snow Leopard Trust and Wildlife Institute of India, Seattle, Washington, pp 113-120.

Comiso JC (2003) Warming trends in the Arctic from clear sky satellite observations. J Climate 16: 3498-3510.

Cutler TL, Swann DE (1999) Using remote photography in wildlife ecology: a review. Wildlife Soc B 27: 571-581.

Dexel B (2002) The Illegal Trade in Snow Leopards: A Global Perspective. Berlin, Germany: German Society for Nature Conservation.

Dong S, Lassoie J, Shrestha KK, Yan Z, Sharma K, Pariya D (2009) Institutional development for sustainable rangeland resource and ecosystem management in mountainous areas of northern Nepal. J Environ Manage 90: 994-1003.

Farrell LE, Roman J, Sunquist ME (2000) Dietary separation of sympatric carnivores identified by molecular analysis of scats. Mol Ecol 9: 1583-1590.

Fedosenko AK, Blank DA (2001) Capra siberica. Mammal Spe 675: $1-13$.

Forrest JL, Wikramanayake E, Shrestha R, Areendran G, Gyeltshen K, Maheshwari A, Mazumdar S, Naidoo R, Thapa GJ, Thapa G (2012). Conservation and Climate change: Assessing the vulnerability of snow leopard habitat to treeline shift in the Himalaya. Biol Conserv 150: 129-135.

Foster ML, Humphrey SR (1995) Use of highway underpasses by Florida panthers and other wildlife. Wildlife Soc B 23: 95-100.

Fox JL (1989) A review of the status and ecology of the snow leopard. Panthera uncia, 40.

Fox JL (1994) Snow leopard conservation in the wild - a comprehensive perspective on a low density and highly fragmented population. In: Fox JL, Jizeng D (eds) Proceedings of the Seventh International Snow Leopard Symposium (Xining, Qinghai, China, July 25-30, 1992). International Snow Leopard Trust, Seattle, Washington, pp 3-15.

Fox JL, Sinha SP, Chundawat RS, Das PK (1991) Status of the snow leopard Panthera uncia in North-west India. Biol Conserv 55: 283-298.

Fuller TK, Sievert PR (2001) Carnivore demography and the consequences of changes in prey availability. In: Gittleman JL, Funk SM, MacDonald DW, Wayne RK (eds) Carnivore conservation. Cambridge University Press, Cambridge, United Kingdom, pp 163-178.

Gaston KJ, Jackson SF, Cantu-Salazar L, Cruz-Pinon G (2008) The ecological performance of protected areas. Annu Rev Ecol Evol S 39: 93-113. 
Gese EM (2001) Monitoring of terrestrial carnivore populations. In: Gittleman JL, Funk SM, Macdonald DW, Wayne RK (eds) Carnivore conservation. Cambridge University Press, Cambridge, United Kingdom, pp 372-396.

Green MJB (1988) Protected areas and snow leopards: their distribution and status. In: Freeman H (ed) Proceedings of the Fifth International Snow Leopard Symposium. International Snow Leopard Trust and Wildlife Institute of India, Seattle, Washington, pp 3-19.

Green MJB, Zhimbiev B (1997) Transboundary protected areas and snow leopard conservation. In: Jackson R, Ahmad A (eds) Proceedings of the 8 th International Snow Leopard Symposium, Islamabad, November 1995. International Snow Leopard Trust, Seattle and WWF-Pakistan, Lahore, pp 194-203.

Habibi K (2003) Mammals of Afghanistan. Zoo Outreach Organisation/USFWS, Coimbatore, India.

Habibi KH (1977) The mammals of Afghanistan: Their distribution and status. UNDP/FAO, Dept. Forests and Range, Ministry of Agriculture, Kabul.

Hannah L, Midgley GF, Millar D (2002a) Climate change-integrated conservation strategies. Global Ecol Biogeogr 11: 485-495.

Harris RB (2008) Pseudois nayaur. In: The IUCN Red List of Threatened Species. Version 2011.1. [Cited 24 Oct 2011.] Available from URL: http://www.iucnredlist.org/details/18536/0.

Heikkinen RK, Luoto M, Araújo MB, Virkkala R, Thuiller W, Sykes MT (2006) Methods and uncertainties in bioclimatic envelope modelling under climate change. Prog Phys Geog 30: 1-27.

Hunter DO, Jackson R (1997) A range-wide model of potential snow leopard habitat. In: Jackson R, Ahmad A (eds) Proceedings of the 8th International Snow Leopard Symposium, Islamabad, November 1995. International Snow Leopard Trust, Seattle and WWF-Pakistan, Lahore, pp 51-56.

Hussain S (2000) Protecting the snow leopard and enhancing farmers' livelihoods: a pilot insurance scheme in Baltistan. Mt Res Dev 20: 226-231.

Hussain S (2003) The status of the snow leopard in Pakistan and its conflict with local farmers. Oryx 37: 26-33.

Ikeda N (2004) Economic impacts of livestock depredation by snow leopard Uncia uncia in the Kanchenjunga Conservation Area, Nepal Himalaya. Environmental Conservation 31: 322-330. DOI 10.1017/S0376892904001778.

IPCC (2001) Climate change 2001: synthesis report. Cambridge University Press, Cambridge, UK, pp 1-396.

Jackson R (1979) Snow leopards in Nepal. Oryx 2: 191-195.

Jackson RM (1996) Home range, movements and habitat use of snow leopard (Uncia uncia) in Nepal. PhD. Thesis, University of London (External Programme), London, United Kingdom.

Jackson R, Ahlborn G (1989) Snow Leopards (Panthera uncia) in Nepal - home range and movements. Natl Geogr Res 5: 161175.

Jackson R, Ahlborn GG (1990) The role of protected areas in Nepal in maintaining viable populations of snow leopards. Int Pedigree Book Snow Leopards 6: 51-69.

Jackson R, Fox JL (1997b) Snow leopard and prey species workshop in Bhutan. Cat News 27: 18-19.

Jackson R, Hunter DO (1996) Snow leopard survey and conservation handbook. Second edition. International Snow Leopard Trust, Seattle, Washington, USA.

Jackson R, Hillard D, Robinson J (from 2004 until now) Snow leopard Conservancy. (Accessed May 6, 2016). http://snow leopardconservancy.org

Jackson R, Mallon D, McCarthy T, Chundaway RA, Habib B (2008) Panthera uncia. The IUCN Red List of Threatened Species. Ver- sion 2008. Avaible from URL: http://dx.doi.org/10.2305/IUCN .UK.2008.RLTS.T22732A9381126.en.

Jackson R, Wang Z, Lu X, Chen Y (1994a) Snow leopards in the Qomolangma Nature Preserve of the Tibet Autonomous region. In: Fox JL, Jizeng D (eds) Proceedings of the Seventh International Snow Leopard Symposium (Xining, Qinghai, China, July 25-30, 1992). International Snow Leopard Trust, Seattle, Washington, pp 85-95.

Jackson R, Wangchuk P, Namgyal T, Kumar E (2000) Report on the second Bhutan SLIMS training workshop. Unpub. Report, International Snow Leopard Trust, Seattle.

Janecka JE, Jackson R, Yuguang Z, Diqiang L, Munkhtsog B, Buckley-Beason V, Murphy WJ (2008) Population monitoring of Snow Leopards using noninvasive collection of scat samples: a pilot study. Anim Conserv 11: 401-411. https://doi. org /10.1111/j.1469-1795.2008.00195.x.

Karanth KU (1995) Estimating tiger (Panthera tigris) populations from camera trapping data using capture-recapture models. Biol Conserv 71: 333-338.

Karanth KU, Nichols JD (1998) Estimation of tiger densities in India using photographic captures and recaptures. Ecology 79: 2852-2862.

Karanth KU, Chundawat RS, Nichols JD, Kumar NS (2004) Estimation of tiger densities in the tropical dry forests of Panna, Central India, using photographic capture-recapture sampling. Anim Conserv 7: 285-290.

Karmacharya D, Janecka J, Ale S, Shakya J, Joshi P, Manandhar S, Shrestha S, Kansakar C, Bista M, Awasthi A (2012) Genetic based population survey of snow leopard (Panthera uncia) in Annapurna Conservation and Rolwaling areas of Nepal. Final Report Submitted to Snow Leopard Conservation Grants, Snow Leopard Network. http://www.snowleopardnetwork.org /GrantFinalReports/KarmacharyaFinal11.pdf

Koshkarev EP (1989) The Snow Leopard in Kirgizia. Ilim Publishers, Frunze, Kirgizia, USSR (in Russian).

Koshkarev E, Vyrypaev V (2000) The snow leopard after the breakup of the Soviet Union. Cat News 32: 9-11.

Koshkarev EP (1996) The snow leopard in its northeastern range. Cat News 25: 10.

Kreuzberg-Mukhina E, Esipov A, Aromov B, Bykova E, Vashetko E (2002) Snow leopard and its protection in Uzbekistan. In: McCarthy TM, Weltzin J (eds) Contributed Papers to the Snow Leopard Survival Strategy Summit. International Snow Leopard Trust, Seattle, Washington, USA, pp 134-135, Available at http://www.snowleopard.org/sln

Lawler JJ, White D, Neilson RP, Blaustein AR (2006) Predicting climate-induced range shifts: model differences and model reliability. Global Change Biol 12: 1568-1584.

Li J, Wang D, Yin H, Zhaxi D, Jiagong Z, Schaller GB, Mishra Ch, McCarthy TM, Wang H, Wu L, Xiao L, Basang L, Zhang Y, Zhou Y, Lu Z (2013) Role of Tibetan Buddhist Monasteries in Snow Leopard Conservation. Conserv Biol 28: 87-94. DOI: 10.1111/cobi.12135.

Liao Y (1994) Snow leopard distribution, purchase locations and conservation in Qinghai Province, China. In: Fox JL, Jizeng D (eds). Proceedings of the Seventh International Snow Leopard Symposium (Xining, Qinghai, China, July 25-30, 1992). International Snow Leopard Trust, Seattle, Washington, pp 65-72.

Locky H, Mackey B (2009) The nature of climate change: reunite international climate change mitigation efforts with biodiversity conservation and wilderness protection. Int J Wilderness 15: 7-14.

Lovari S, Boesi R, Minder I (2009) Restoring a keystone predator may endanger a prey species in a human altered ecosystem: the 
return of the snow leopard to Sagarmatha National Park. Animal Conserv 12: 559-570.

Mace RD, Minta SC, Manley TL, Aune KA (1994) Estimating grizzly bear population size using camera sightings. Wildlife Soc B 22: $74-83$.

Mackenzie DI, Royle A (2005) Designing occupancy studies: general advice and allocating survey effort. J Appl Ecol 42: 1105-1114.

Mallon DP, Bacha MS (1989) Ecology and management of the Hemis National Park. Report to the Department of Wildlife Protection, Jamnu and Kashmir Government.

Marsh DM, Trenham PC (2008) Current trends in plant and animal population monitoring. Conserv Biol 22: 647-655.

McCarthy J, McCarthy KP, Fuller TK, McCarthy TM (2010) Assessing Variation in Wildlife Biodiversity in the Tien Shan Mountains of Kyrgyzstan Using Ancillary Camera-trap Photos. Mt Res Dev 30: 295-301. DOI 10.1659/MRD-JOURNAL -D-09-00080.1.

McCarthy KP, Fuller TK, Ming M, McCarthy TM, Waits L (2008) Assessing Estimators of Snow Leopard Abundance. J Wildlife Manage 72: 1826-1833. DOI: 10.2193/2008-040.

McCarthy TM (2000) Ecology and conservation of snow leopards, Gobi brown bears and wild Bactrian camels in Mongolia. Ph.D. Dissertation, University of Massachusetts, Amherst.

McCarthy TM, Chapron G (2003) Distribution and population estimates for Snow Leopard. Snow Leopard survival strategy. ISLT and SLN, Seattle, USA.

McCarthy TM, Chapron G (2003) Snow Leopard Survival Strategy. Seattle, USA: International Snow Leopard Trust and Snow Leopard Network.

McCarthy T, Fuller TK, Munkhtsog B (2005) Movements and activities of snow leopards in Southwestern Mongolia. Biol Conserv 124: 527-537.

McCarty TM, Chapron G (2003) Ecological consequences of recent climate change. Conserv Biol 15: 320-331.

McEwan TE (1995) Short range locator system. United States of Patent. (number of patent US 5589838 A).

Mishra C, Allen P, McCarthy T, Madhusudan MD, Bayarjargal A, Prins HHT (2003) The role of incentive programs in conserving the snow leopard. Conserv Biol 17: 1512-1520.

Mishra C, Wierenvan SE, Ketner P, Heitkonig MA, Prins HHT (2004) Competition between domestic livestock and wild bharal Pseudois nayaur in the Indian Trans-Himalaya. J Appl Ecol 41: 344-354.

Myers N, Mittermier RA, Mittermier CG, Fonseca GAB, Kent J (2000) Biodiversity hotspots for conservation priorities. Nature 40: 853-858.

Namgail T, Fox JL, Bhatnagar YV (2007) Habitat shift and time budget of the Tibetan argali: the influence of livestock grazing. Ecol Res 22: 25-31.

Noras S (2015) Afghanistan. Snowleopardblog. (Accessed May 8, 2016). http://snowleopardblog.com/projects/afghanistan

Noras S (2015) Mongolia. Snowleopardblog. (Accessed May 8, 2016). http://snowleopardblog.com/projects/mongolia

Nowell K, Schipper J, Hoffmann M (2007) Re-evaluation of the Felidae of the 2008 IUCN Red List. Cat News 47: 5.

O’Brien TG, Kinnaird MF, Wibisono HT (2003) Crouching tigers, hidden prey: Sumatran tiger and prey populations in a tropical forest landscape. Anim Conserv 6: 131-139.

Oli MK, Taylor IR, Rogers ME (1993) Diet of the snow leopard (Panthera uncia) in the Annapurna Conservation Area, Nepal. J Zool 231: 365-370.

Oli MK, Taylor IR, Rogers ME (1994) Snow leopard Panthera uncia predation of livestock: an assessment of local perceptions in the Annapurna Conservation Area, Nepal. Biol Conserv 68: 63-68.

Oli M, Rogers ME (1991) Seasonal pattern in group size and population composition of blue sheep in Manang, Nepal. J Wildlife Manage 60: 797-801.

Olson D, Dinerstein E (1998) The Global 200. A representation approach to conserving the Earth's most biologically valuable ecoregions. Conserv Biol 12: 502-515.

Onorato D, White C, Zager P, Waits LP (2006) Detection of predator presence at elk mortality sites using mtDNA analysis of hair and scat samples. Wildlife Soc B 34: 815-820.

Otis DL, Burnham KP, White GC, Anderson DR (1978) Statistical inference from capture data on closed animal populations. Wildlife Monogr 62.

Paltsyn MY, Spitsyn SV, Kuksin AN, Istomov SV (2012) Snow Leopard Conservation in Russia.

Pearson RG, Dawson TP (2003) Predicting impacts of climate change on the distribution of species: are bioclimate envelope models useful? Global Ecol Biogeogr 12: 361-371.

Pei JQ (1998) An evaluation of using auto-trigger cameras to record activity patterns of wild animals. Taiwan J Forest Sci 13: 317-324.

Pereira HM, Cooper HD (2006) Towards the global monitoring of biodiversity change. Trends Ecol Evol 21: 123-129.

Petocz RG (1978) Report on the Afghan Pamir, Part I Exological reconnaissance. UNDP/FAO Project AFG/74/014. Field Document No. 6.

Rajput ASD (2009) Project to save Snow Leopard launched. Curr Sci 96: 755-756.

Roberts TJ (1977) The mammals of Pakistan. Ernest Benn, London and Tonbridge.

Rowcliffe JM, Field J, Turvey ST, Carbone C (2008) Estimating animal density using camera traps without the need for individual recognition. J Appl Ecol 45: 1228-1236.

Sathyakumar S, Bashir T, Bhattacharya T, Poudyal K (2011) Assessing mammal distribution and abundance in intricate eastern Himalayan habitats of Khangchendzonga, Sikkim, India. Mammalia 75: 257-268. DOI 10.1515/MAMM.2011.023.

Sayer JA (1980) The conservation of the snow leopard (Uncia uncia) in Afghanistan. Int Pedigree Book Snow Leopards 2: 55-61.

Schaller G (1977) Mountain Monarchs: Wild Sheep and Goats of the Himalaya. University of Chicago Press, Chicago and London. DOI: http://dx.doi.org/10.2307/1379791.

Schaller G (1980) Stones of silence: journeys in the Himalaya. Viking Press, New York, New York, USA.

Schaller GB (1998) Wildlife of The Tibetan Steppe. The University Chicago Press, Chicago.

Schaller GB, Tserendeleg J, Amarsanaa G (1994) In: Fox JL, Jizeng D (eds) Proceedings of the Seventh International Snow Leopard Symposium (Xining, Qinghai, China, July 25-30, 1992). International Snow Leopard Trust, Seattle, Washington, pp 33-42.

Schellhom M, Simmons D (2000) Kangchenjunga Conservation Area tourism plan 2001-2006 (draft). Unpublished report, Lincoln International (1995) Ltd, New Zealand, for His Majesty's Government of Nepal, Department of National Parks and Wildlife Conservation and WWF Nepal Program, Kathmandu, Nepal.

Schofield G, Bishop ChM, MacLean G, Brown P, Baker M, Katselidis KA, Dimopoulos P, Pantis JD, Hays GC (2007) Novel GPS tracking of sea turtles as a tool for conservation management. J Exp Mar Biol Ecol 347: 58-68.

Seventh International Snow Leopard Symposium (Xining, Qinghai, China, July 25-30, 1992). International Snow Leopard Trust, Seattle, Washington. 
Sharma E, Tsering K (2009) Climate change in the Himalayas: the vulnerability of biodiversity. Sustain Mount Develop 55: 10-12.

Sheng L, Dajun W, Xiaodong G, William J, Mc Shea WJ (2010) Beyond pandas, the need for a standardized monitoring protocol for large mammals in Chinese nature reserves. Biodivers Conserv 19: 3195-3206.

Smirnov MN, Sokolov GA, Zyryanov AN (1990) The snow leopard (Uncia uncia Schreber 1776) in Siberia. Int Pedigree Book Snow Leopards 6: 9-15.

Sopin LV (1977) The snow leopard in the Altai. In: Sokolov VE (ed) Rare species of mammals and their conservation. Materials of the Second All-Union Conference. Nauka, Moscow (in Russian).

Stein AB, Fuller TK, Marker LL (2008) Opportunistic use of camera traps to assess habitat-specific mammal and bird diversity in north-central Namibia. Biodivers Conserv 17: 3579-3587.

Theile S (2003) Fading footprints: the killing and trade of snow leopards. TRAFFIC International, Cambridge, UK.

Thomas CD, Cameron A, Green RE, Bakkenes M, Beaumont LJ, Collingham YC, Erasmus BFN, Ferreira de Siqueira M, Grainger A, Hannah L, Hughes L, Huntley B, Van Jaarsveld AS, Midgely GE, Miles L, Ortega-Huerta MA, Peterson AT, Phillips OL, Williams SE (2004) Extinction risk from climate change. Nature 427: 145-148.

Thuiller W (2007) Climate change and ecologist. Nature 448: $550-552$.

Waits LP, Buckley-Beason VA, Johnson WE, Onorato D, McCarthy T (2007) A select panel of polymorphic microsatellite loci for individual identification of snow leopards (Panthera uncia). Mol Ecol 7: 311-314.

Wegge P (1979) Aspects of the population ecology of blue sheep in Nepal. J Asian Ecol 1: 10-20.

Whitefield J (1998) A saola poses for the camera. Nature 396: 410.
Wilson GJ, Delahay RJ (2001) A review of methods used to estimate the abundance of terrestrial carnivores using field signs and observation. Wildlife Res 28: 151-164. https://doi .org/10.1071/WR00033.

Wilson KR, Anderson DR (1985) Evaluation of two density estimators of small mammal population size. J Mammal 66: $13-21$.

Wingard JR, Zahler P (2006) Silent Steppe: The Illegal Wildlife Trade Crisis in Mongolia. Mongolia Discussion Papers, East Asia and Pacific Environment and Social Development Department. Washington D.C., World Bank.

Wolf M, Ale SB (2009) Signs at the top: habitat features influencing Snow Leopard Uncia uncia activity in Sagarmatha National Park, Nepal. J Mammal 90: 604-611. https://doi.org /10.1644/08-MAMM-A-002R1.1.

Xu A, Jiang Z, Li Ch, Guo J, Da S, Cui Q, Yu S, Wu G (2008) Status and conservation of the snow leopard Panthera uncia in the Gouli Region, Kunlun Mountains, China. Fauna and Flora International, Oryx 42: 460-463.

Xu J, Grumbine R, Shrestha A, Eriksson M, Yang X, Wang Y, Wilkes A (2009) The melting Himalayas: cascading effects of climate change on water, biodiversity, and livelihoods. Conserv Biol 23: 520-530.

Zhang Y, He L, Duo H, Li D, Jin K (2009) A preliminary study on the population genetic structure of snow leopard (Uncia uncia) on Qinghai Province utilizing fecal DNA. Acta Theriol Sinica 29: 310-315.

Zhirjakov VA (1990) On the ecology of snow leopard in the Zailisky-Alatau (northern Tien Shan). Int Pedigree Book Snow Leopards 6: 25-30.

Zhou X, Song J, Wang F (2014) The application of extracting DNA from noninvasive samples in feline species identification. Acta Theriol Sinica 34: 138-148. 